Florida International University FIU Digital Commons

\title{
The contribution of Higher Education to economic development in a globalized environment
}

Domingo G. Echevarria

Florida International University

DOI: $10.25148 /$ etd.FI15101263

Follow this and additional works at: https://digitalcommons.fiu.edu/etd

Part of the Higher Education Commons

\section{Recommended Citation}

Echevarria, Domingo G., "The contribution of Higher Education to economic development in a globalized environment" (2009). FIU Electronic Theses and Dissertations. 3114.

https://digitalcommons.fiu.edu/etd/3114 
FLORIDA INTERNATIONAL UNIVERSITY

Miami, Florida

THE CONTRIBUTION OF HIGHER EDUCATION TO ECONOMIC DEVELOPMENT IN A GLOBALIZED ENVIRONMENT

A dissertation submitted in partial fulfillment of the

requirements for the degree of

DOCTOR OF EDUCATION

in

HIGHER EDUCATION

by

Domingo G. Echevarria

2009 
To: Interim Dean Kingsley Banya

College of Education

This dissertation, written by Domingo G. Echevarria, and entitled The Contribution of Higher Education to Economic Development in a Globalized Environment, having been approved in respect to style and intellectual content, is referred to you for judgment.

We have read this dissertation and recommend that it be approved.

Roger Geertz Gonzalez

Benjamin Baez

Maria Willumsen

Lynn Ilon, Major Professor

Date of Defense: February 26, 2009

The dissertation of Domingo G. Echevarria is approved.

Interim Dean Kingsley Banya

College of Education

Dean George Walker

University Graduate School

Florida International University, 2009 
(C) Copyright 2009 by Domingo G. Echevarria

All rights reserved. 


\section{DEDICATION}

I dedicate this dissertation to my wife, Gloria. Without her patience, support, understanding, encouragement, and most of all love, the completion of this work would not have been possible. 


\section{ACKNOWLEDGMENTS}

I wish to thank the members of my committee for their guidance, support, and patience. Their gentle but firm direction has been most appreciated. Dr. Roger Gonzalez was my first committed member, and he alone guided me during the early stages of my research. Dr. Benjamin Baez wisely helped me reconcile theory and practice in education. Dr. Maria Willumsen assisted me with the theoretical issues of economics. Finally, I would like to thank my major professor, Dr. Lynn Ilon. Without her advice and leadership I would not have been able to accomplish the difficult task of analyzing education from the perspective of economics.

I have found my coursework throughout the Higher Education program to be stimulating and thoughtful, providing me with the tools with which I conducted this project. 
ABSTRACT OF THE DISSERTATION

THE CONTRIBUTION OF HIGHER EDUCATION TO ECONOMIC

DEVELOPMENT IN A GLOBALIZED ENVIRONMENT

by

Domingo G. Echevarria

Florida International University, 2009

Miami, Florida

Professor Lynn Ilon, Major Professor

Amidst concerns about achieving high levels of technology to remain competitive in the global market without compromising economic development, national economies are experiencing a high demand for human capital. As higher education is assumed to be the main source of human capital, this analysis focused on a more specific and less explored area of the generally accepted idea that higher education contributes to economic growth. The purpose of this study, therefore, was to find whether higher education also contributes to economic development, and whether that contribution is more substantial in a globalized context.

Consequently, a multiple linear regression analysis was conducted to support with statistical significance the answer to the research question: Does higher education contributes to economic development in the context of globalization? The information analyzed was obtained from historical data of 91 selected countries, and the period of time of the study was10 years (1990-2000). Some variables, however, were lagged back 5,10 or 15 years along a 15-year timeframe (1975-1990). The resulting comparative static model was based on the Cobb-Douglas production function and the Solow model to 
specify economic growth as a function of physical capital, labor, technology, and productivity. Then, formal education, economic development, and globalization were added to the equation.

The findings of this study supported the assumption that the independent contribution of the changes in higher education completion and globalization to changes in economic growth is more substantial than the contribution of their interaction. The results also suggested that changes in higher and secondary education completion contribute much more to changes in economic growth in less developed countries than in their more developed counterparts.

As a conclusion, based on the results of this study, I proposed the implementation of public policy in less developed countries to promote and expand adequate secondary and higher education systems with the purpose of helping in the achievement of economic development. I also recommended further research efforts on this topic to emphasize the contribution of education to the economy, mainly in less developed countries. 


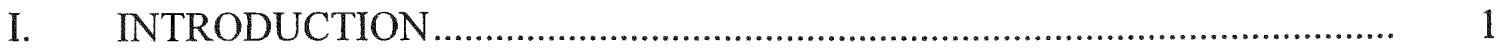

Background ....................................................................................... 1

Problem Statement ..............................................................................

Research Question............................................................................. 2

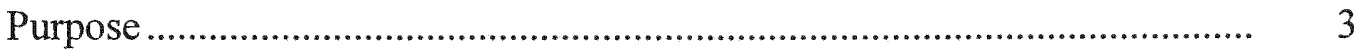

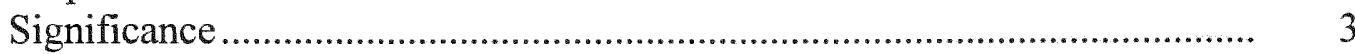

Delimitations .......................................................................................... 4

Definition of Terms .............................................................................. 5

Economic Growth............................................................................... 5

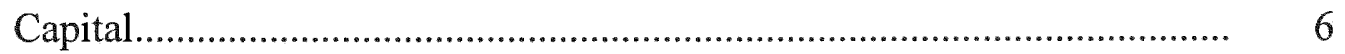

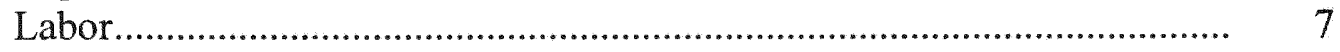

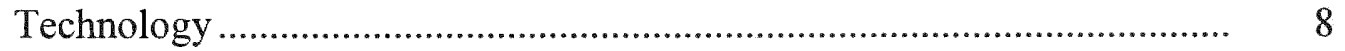

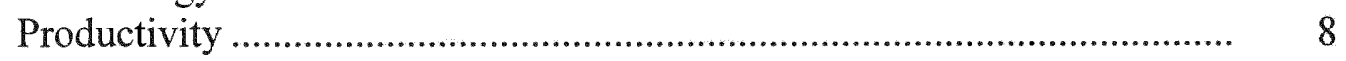

Economic Development ........................................................................... 9

Human Capital .................................................................................... 10

Human Development .......................................................................... 11

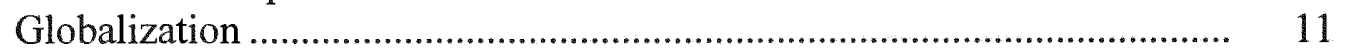

Foreign Direct Investment (FDI) ...................................................... 12

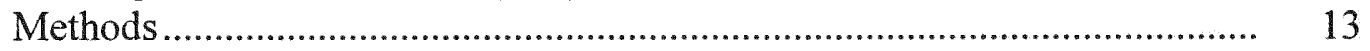

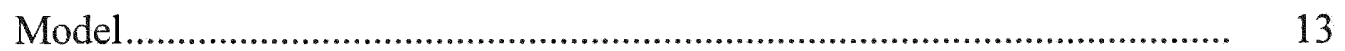

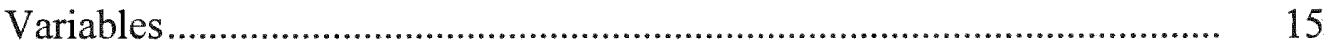

Dissertation Outline....................................................................... 17

II. LITERATURE REVIEW ................................................................... 18

Contribution to the Current Literature …................................................... 19

The Production Function and Economic Growth........................................ 20

Economic Development ......................................................................... 21

Human Capital and Economic Growth ....................................................... 23

Education as a Capital Good ..................................................................... 28

Human Capital in a Globalized Context........................................................ 35

Summary of the Literature Review ........................................................... 37

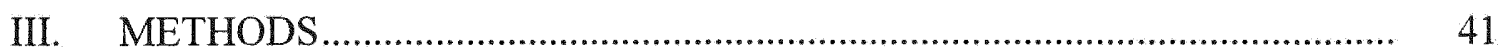

Research Question.............................................................................. 41

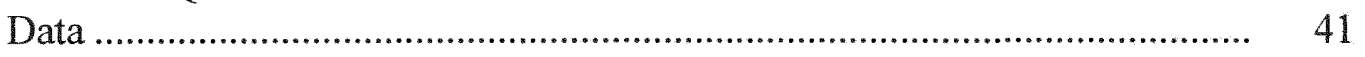

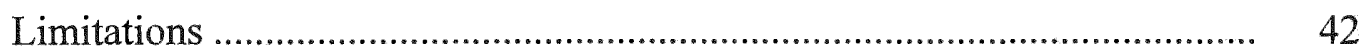

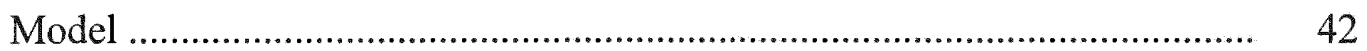

The Production Function ................................................................... 43

Education Components......................................................................... 45

Economic Development Component.................................................... 45

Globalization Component ..................................................................... 46 


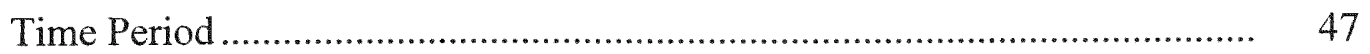

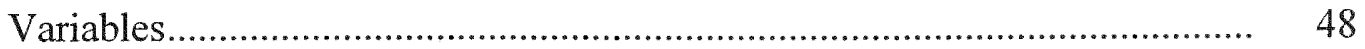

Dependent Variable .............................................................................. 50

Cobb-Douglas Components ............................................................ 50

The Solow Model Component …........................................................... 52

Education Components ...................................................................... 52

Education Lagging Procedure ............................................................... 53

Economic Development Component.......................................................... 54

The Globalization Component …............................................................. 55

Data Analysis Procedure ..................................................................... 56

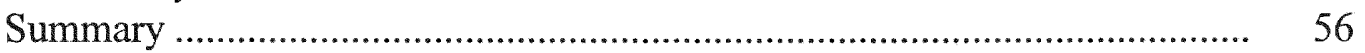

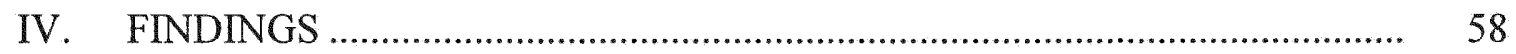

Interaction of Higher Education and Globalization ..................................... 60

Higher Education and Economic Growth ................................................. 64

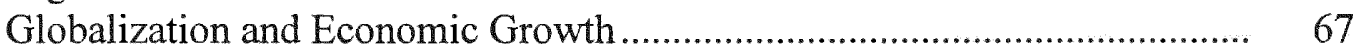

Higher Education and Economic Development ........................................... $\quad 70$

Higher Education in Top Mid to Highly Developed Economies............... 70

Higher Education in Bottom Mid to Less Developed Economies ............. $\quad 72$

Higher Education Preceding Levels ........................................................... $\quad 76$

Secondary Education and per Capita Income ............................................ $\quad 76$

Secondary Education in Top Mid to Highly Developed Economies .......... 78

Secondary Education in Bottom Mid to Less Developed Economies ........ 81

Summary of Findings ...............................................................................

V. DISCUSSION AND CONCLUSIONS ..................................................... 86

Discussion of Findings ............................................................................ 86

Higher Education and Globalization......................................................... 86

Higher Education and Economic Development ....................................... 88

Secondary Education and Economic Development ................................ $\quad 89$

The Importance of Primary Education ...................................................... 91

Significance of the Study ..................................................................... 92

Developed Countries............................................................................ 92

Less Developed Countries....................................................................... 94

Corporate Social Responsibility............................................................ 94

New Windows into Research .................................................................... 95

The Perspective of Change.................................................................. 96

Research Timeframe ........................................................................... 96

Absolute Value Perspective - Analysis-by-Year ..................................... 97

Country-by-Country Analysis ............................................................... 97

Comparative Education ........................................................................ 98

Analysis by other Categories ................................................................. 98

Labor Demand Pressures.................................................................... 100 
Enrollment and Retention .....

An Integrated Education System............................................................ 101

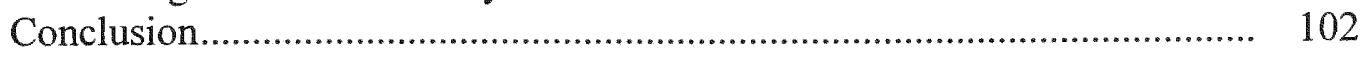

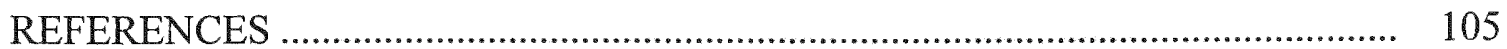

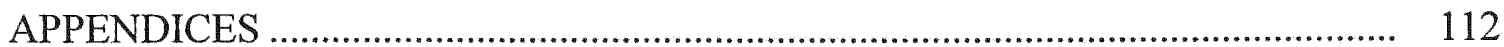

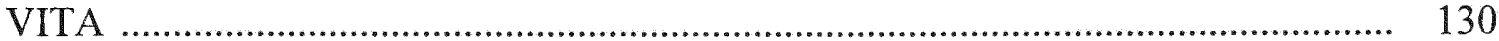




\section{LIST OF TABLES}

TABLE

PAGE

1. Model Analyzed in the Literature Reviewed................................ 38

2. Summary of Variables .................................................... 49

3. Variable Definitions................................................... 59

4. Descriptive Statistics of the Variables of the Model Run for All the Countries Selected for this Study

5. Model Summary Displaying the Effect of Adding the Higher Education and Globalization Interaction Term $(\mathrm{N}=91)$

6. Effect of Higher Education and Globalization Interaction on the

Predictions of Changes in Income $(\mathrm{N}=91)$.

7. Interaction of Higher Education and Foreign Direct Investment on

Countries Grouped by High and Low Development Indicators $(\mathrm{N}=91)$

8. Model Summary Displaying the Effect of Adding the Higher

Education Term $(\mathrm{N}=91)$

9. Effect of Higher Education on the Predictions of Changes in Income

$(\mathrm{N}=91)$

10. Model Summary Displaying the Effect of Adding the Globalization

Term $(\mathrm{N}=91)$.

11. Effect of Globalization on the Predictions of Changes in Income $(\mathrm{N}=91) \ldots \ldots .69$

12. Model Summary Displaying the Effect of Adding the Higher Education Term in Top Mid to Highly Developed Economies $(\mathrm{N}=41)$.

13. Effect of Higher Education on the Predictions of Changes in Income in Top Mid to Highly Developed Economies $(\mathrm{N}=41)$.

14. Model Summary Displaying the Effect of Adding the Higher Education Term in Bottom Mid to Less Developed Economies $(\mathrm{N}=50)$

15. Effect of Higher Education on the Predictions of Changes in Income

in Bottom Mid to Less Developed Economies $(\mathrm{N}=50)$ 
16. Model Summary Displaying the Effect of Adding the Secondary Education Term $(\mathrm{N}=91)$

17. Effect of Secondary Education on the Predictions of Changes in Income $(\mathrm{N}=91)$.

18. Model Summary Displaying the Effect of Adding the Secondary Education Term in Top Mid to Highly Developed Economies $(\mathrm{N}=41)$

19. Effect of Secondary Education on the Predictions of Changes in Income in Top Mid to Highly Developed Economies $(\mathrm{N}=41)$

20. Model Summary Displaying the Effect of Adding the Secondary Education Term in Bottom Mid to Less Developed Economies $(\mathrm{N}=50)$

21. Effect of Secondary Education on the Predictions of Changes in Income in Bottom Mid to Less Developed Economies $(\mathrm{N}=50)$. 


\section{LIST OF FIGURES}

FIGURE

PAGE

1. Comparison of the coefficients of higher education $(p=.01)$

and globalization $(p=.05)$ variables and their interaction $(p=.05)$

2. Model statistical strength measured by the multiple correlation coefficient (R)

3. Comparison of the per capita income variance explained by changes in the completion of higher education and secondary education in all countries.

4. Comparison of the per capita income variance explained by changes in the completion of higher education and secondary education in all countries with the variance explained in developed countries.

5. Comparison of the per capita income variance explained by changes in higher education and secondary education in developed and less developed countries. 


\section{LIST OF ACRONYMS}

CEPAL Comisión Económica para América Latina y el Caribe (ECLAC)

BMA Bayesian Model Averaging

CSR Corporate Social Responsibility

ECLAC Economic Commission for Latin America and the Caribbean

FDI Foreign Direct Investment

GDP Gross Domestic Product

HDI Human Development Index

IMF International Monetary Fund

IND Inward Foreign Direct Investment Performance Index

LDC Less Developed Countries

MNE Multinational Enterprise

R \& D Research and Development

TNC Transnational Corporations

UN United Nations

UNCTAD United Nations Conference on Trade and Development

UNDP United Nations Development Programme

WIPO World Intellectual Property Organization 


\section{CHAPTER I \\ INTRODUCTION \\ Background}

In a globalized environment, competition is lower among different suppliers within an economy than among different economies of the world. Under these circumstances, it is really the whole national economy, not just a single supplier, which struggles to remain efficient, productive, and consequently competitive in the world market.

Higher education is not an exception within globalization. During the last decades, colleges and universities have been changing the way they conduct business, reshaping their organization to meet the demands of the new global environment. This has been mainly due to the role of education in the development of human capital.

In a national economy facing globalization, the market mechanism creates increasing emphasis on the value of human capital. The main reasons are (a) business firms must produce at low cost in order to remain globally competitive, (b) low costs are achieved only at high levels of productivity, (c) high productivity levels are attained through a capital intensive production process (more use of physical capital than labor), and (d) a capital intensive production process implies advanced technology and high levels of human capital necessary to attain it.

\section{Problem Statement}

This study focuses on the increasing demand of national economies for human capital because of their need to achieving higher levels of technology to remain competitive in the global market. To meet that increasing demand for human capital, 
economies must identify reliable, stable, and sustainable sources of human capital and technological development. Several sources of human capital and technology are constantly interacting in the economy. Generational transfer of information in business firms from one generation of worker to the next keeps knowledge and experience building up human capital. On-the-job training, seminars, and workshops are other means to accumulate workforce knowledge. Also, the transfer of technology between the home and host headquarters of multinational corporations and the projects of business firms' research and development (R \& D) departments contribute to the development of technology.

Formal education, however, is thought to be the most reliable, stable, and sustainable source of human capital and technology. This is the most manageable education source that can be modified and expanded through the implementation of public policy. Narrowing the focus, of the three levels of formal education (primary, secondary, and tertiary), it is the tertiary level (higher education) that is the ultimate source of high levels of human capital and technology. Thus, the promotion and development of an adequate educational system, with emphasis in higher education, is a central strategy of national and industry-wide economic development in a globalized environment.

\section{Research Question}

Assuming an increasing demand for human capital to keep adequate levels of economic growth and development in the globalized context, and the role of higher education in the development of human capital, I formulate the following research 
question: Does higher education contribute to economic development in the context of globalization?

\section{Purpose}

Whereas the relationship between education and economic growth has long been theorized and has been studied using a generalized technique of rates-of-return analysis, the assumption that higher education interacts with globalization forces and that it also influences economic development is relatively untested. The purpose of this study, therefore, is to find whether higher education also contributes to economic development, and whether that contribution is more substantial in a globalized context. If this research shows a substantial relationship between higher education and economic development in a globalized environment, high levels of higher education would be considered a necessary condition for a national economy to remain competitive and survive in the global market.

\section{Significance}

If higher education is recognized as the main source of human capital and technology, one of the bases of an adequate education system would be a wider access to schooling. The preparation of students in education institutions is comprehensive, in contrast with that of in-the-job training, seminars, and other informal sources, which concentrate only on those particular techniques that workers need to learn and apply to the production process. In my opinion, more graduates from higher education can be translated into more individuals with high sense of citizenship, intellectual development, and improved lifestyle. Therefore, the development of higher education would influence not only economic development, but human and social development as well. 


\section{Delimitations}

With many different economic models, researchers have found statistical significance in the direct relationship between education and economic growth. Therefore, the focus of this analysis is to build on this established relationship. The research question is not asking whether there is a direct relationship between education and economic growth - that relationship has been well established in the literature by many scholars such as Denison (1961); Mowery and Rosenberg (1989); Benhabib and Spiegel (1992); and Mankiw, Romer, and Weil (1992). Rather, this research question asks whether education contributes to economic development (not just growth) in the context of globalization.

Because formal education is generally structured in three different levels (primary, secondary and tertiary), these levels can be considered rough measures of human capital embedded in the workforce. Such a workforce can likewise be structured in three different levels-low skilled, medium skilled, and highly skilled workforces. This comparison suggests a relationship between each education level and the corresponding skill level of the workforce. Even though the three education levels are included in the data analysis, this study focuses on the effect of higher education on the development of a highly skilled workforce as the main contributor to economic development.

With respect to the data, only 91 countries that better fit the purpose of this study were included in the analysis. First, the countries chosen have the Inward Foreign Direct Investment (FDI) Performance Index calculated by the United Nations Conference on Trade and Development (UNCTAD). The main reason for this delimitation is to isolate as 
much as possible the relationship between education and globalization. Then, the selected countries have also the Human Development Index (HDI) calculated by the United Nations Development Programme (UNDP). This index measures economic development in the model. Finally, the countries studied are also included in the Barro-Lee educational attainment dataset. This indicator is used in this model to measure the graduates at each level of education as a percentage of the population.

The globalization of an economy can be measured, among others things, by the influence of foreign capital, either by absolute figures or rate of change, or by its rate of growth. The absolute influence is the static measure of the level of foreign capital, whereas the rate of growth is the dynamic measure of its changes. If the absolute measure is chosen, some countries may have a high and stable level of foreign capital, but higher education may not change their economic picture much. If rate of growth is chosen, other countries rapidly gaining in foreign capital (but perhaps with a low level of it) may also experience increases in the demand for higher education derived from that rapid gain. As I can generalize across one choice but not the other, this study focuses only on the rate of growth of foreign capital, the measure that better fits this research.

\section{Definition of Terms}

\section{Economic Growth}

Economic growth is properly defined as the ability to produce a larger total output (McConnell \& Brue, 2002), in other words, an increase in output or an expansion of the production possibilities of the economy (Schiller, 2006). Economic growth is the dependent variable in this study and is measured by changes in per capita income. Per capita income is the proportion of output corresponding to each member of a country's 
population. It is calculated by dividing the country's value of total output by the country's population. This indicator is used in this study instead of total output because per capita income is not affected by changes in population. This assumption can be illustrated with the following example. The total income of an economy in 2001 is $\$ 800$ million and $\$ 840$ million in 2005 . The total population of this economy in 2001 is 50,000 and 60,000 in 2005 . Per capita income in 2001 , therefore, is $\$ 16,000$ ( $\$ 800$ million / $50,000)$ and $\$ 14,000$ (\$840 million / 60,000) in 2005. Consequently, this economy experienced $\$ 40$ million increase in total income $(840-800)$, but individuals are $\$ 2,000$ poorer $(\$ 16,000-\$ 14,000)$. An economy really grows not only when its total income increases, but when its per capita income increases as well.

\section{Capital}

Human-made resources, such as buildings, machinery, and equipment, which do not directly satisfy human wants and instead are used to produce consumable goods and services, are defined as capital (McConnell \& Brue, 2005). It is commonly known as physical capital to differentiate it from human capital, later defined in this section. Capital can be measured by its stock in the economy. It has been argued, however, that the stock of capital is a collection of heterogeneous machines (Blaug, 1992). Thus, it is measured as a homogeneous value in monetary terms. In this study, capital is also measured in monetary terms, but by its formation. Capital formation is equivalent to investment (Boyes, 1984). It measures how much more capital has been added to the capital stock of the economy in a year. Measuring capital change as change in capital formation is consistent in this model with the measuring of globalization by change in 
foreign investment, and with capital accumulation as a condition of economic development.

\section{Labor}

According to McConnell and Brue (2005), labor is the people's talents and efforts that are used to produce goods and services. Hypothetically, households could use only their own labor to produce the goods they need (Barro, 1984). In a modern society, however, it is virtually impossible for households alone to satisfy their own consumption needs. Only the combined efforts of individuals willing and allowed to participate in the production process of the economy can meet the wants of households. That group of individuals potentially involved in the production process who want to achieve a mix of real income and leisure that is most satisfactory to them (Branson, 1979), and who are age 16 and over (Ayers \& Collinge, 2005) is known as the workforce. In economic terms, therefore, labor is equivalent to the workforce.

Labor can be measured by the cost of the workforce. Using that method, the total amount of salaries and wages paid to the workforce would be the cost of the workforce. The inconvenience of this method is that wage differentials could make the comparison of labor among different countries inaccurate. In this study, labor is measured by the change in the number of members of the workforce. This method is consistent with the measure of the education variables. The education variables in this study measure the change in completion, the change of the number of students graduating at different levels of education. Eventually, most of the graduates at the secondary and tertiary levels of education become qualified members of the workforce. 


\section{Technology}

Technology is the method of producing products (Mansfield \& Behravesh, 2001). A low level of technology is translated into a labor-intensive production process (more use of labor than physical capital), whereas a capital-intensive one (more use of physical capital than labor) is characterized by a high technology level (Schiller, 2006). The direct relationship between technology and productivity can be illustrated with a hypothetical example. A machine produces five units of a product per hour operated by five workers (one unit of output per worker), and it is replaced with a high technology machine that also produces five units per hour but is operated by only one worker (five units of output per worker). This example shows that by increasing the level of technology the production process becomes more capital-intensive, and the productivity increases from one to five units per worker. As the changes in the proportion of capital and labor used in the production process are mainly due to changes in technology, the measure of technology in this study is the proportion of physical capital to labor. It is calculated by dividing the value of physical capital by the number of individuals in the workforce. The result is the value of physical capital used per worker. The higher the value of physical capital per worker, the more capital intensive the production process and the higher the level of technology will be.

\section{Productivity}

Within the field of economics, productivity and technology are two directly related terms. Changes in technology in one direction lead to changes in productivity in the same direction. According to Gaither and Gray (1996), productivity means the amount of products or services produced with the resources used. Productivity can be 
measured for a particular period of time dividing the quantity of products or services produced by the amount of resources used. The resources used could be any of the factors of production: natural resources, labor, or capital. For the purpose of this study, productivity was measured based on the proportion of output to labor, in other words, by dividing the value of output by the number of members in the workforce. The results obtained were the value of the average amount of output produced by one member of the workforce. The higher the value of output produced by one unit of labor, the higher the productivity will be.

\section{Economic Development}

It is important to understand the difference between economic growth and economic development. Sometimes both terms are used interchangeably when referring to economic growth, giving rise to confusion. Economic development is a much broader concept. For the purpose of this study, economic development is assumed to be the construction and maintenance of an infrastructure that makes economic growth sustainable. A simple increase in production does not satisfy the real economic needs of society. Resources must be allocated to produce what society needs for consumption, and also what the economy needs to make growth sustainable. Some characteristics of economic development are: (a) equitable distribution of output that translates into social and political stability, the ideal environment for businesses to operate; (b) constant development of the workforce's working capability (human capital); and (c) continuous increase in the level of technology of the production process of business firms. This study has a greater emphasis on economic development than on economic growth. For that purpose, a variable of economic development is included in the model, and it measures a 
composite index of human development, a comprehensive indicator that includes necessary conditions of economic development.

\section{Human Capital}

The human capital theory is a set of principles devised to explain the market value possessed by an individual or in aggregate terms by the workforce, which is derived from the acquisition of skills with specific industrial application. These skills can be acquired through, among other ways, generational transfer of information, on-the-job training, seminars, workshops, and formal education. This study does not focus on the human capital of an individual, but on the aggregate human capital of the workforce. For the purpose of this study, the only source of skill acquisition that is considered is formal education, specifically, higher education. For that reason, the measure of the variables of primary, secondary, and higher education used in the model of this study is the equivalent measure of the human capital embedded in the workforce.

Education can be measured in several ways, such as levels of completion and enrollment and amount of education expenditures. In this study, education is measured by the number of students completing each of the three corresponding levels of formal education (primary, secondary, and tertiary). The main reason to choose completion is that the measure for graduates is consistent with the measure for members of the workforce. Nevertheless, there is a timing issue since the effect of education is not immediate. To address this problem, education was lagged to measure the number of graduates when they might impact the workforce capability.

The term human capital is clarified in this section because of its extensive use in studies included in the literature review, and because it is analyzed in this study as a 
general concept, of which education is a component. This study, however, does not focus on human capital per se. Education, and more specifically higher education, is the focus of analysis.

\section{Human Development}

Human development is both the goal of economic development and a means to achieve it, and it is derived from the integral development of individuals.

Human development is about much more than the rise or fall of national incomes. It is about creating an environment in which people can develop their full potential and lead productive, creative lives in accord with their needs and interests. People are the real wealth of nations. Development is thus about expanding the choices people have to enable them to lead lives that they value. And it is thus about much more than economic growth, which is only a means albeit a very important one - of enlarging people's choices (Human Development Reports - United Nations Development Programme [UNDP], n.d.).

Social development is measured in this study by the Human Development Index (HDI), a fraction ranging between the extreme values of human development 0 and 1 , calculated by the United Nations Development Programme (UNDP). HDI summarizes a country's average achievements in health, knowledge, and a decent standard of living. (Human Development Reports - UNDP, n.d.).

\section{Globalization}

The concept of globalization is too broad to be framed by a narrow definition, since it not only refers to an economic phenomenon, but also to social, political, and cultural interactions among most of the nations of the world. Therefore, globalization does not have a single cause or start at a particular time. From this viewpoint, any action creating interdependence among different countries at any time in history, such as international trade, migration, transportation, telecommunication, and cultural exchange, 
could be considered as a manifestation of globalization. Regardless of the importance of the social, political, cultural, and other aspects of globalization, however, this study refers only to the economic aspect of it.

The global influence on an economy can be measured by different factors, such as international trade (imports and exports) and capital flows (inflows and outflows). Globalization in this study is measured by capital inflows, specifically inward foreign direct investment (FDI). Inward FDI is assumed to be the most influential of all forms of economic globalization since it implies the establishment of multinational enterprises (MNE). The main characteristics that make MNEs so influential are their tendency to be permanent and the corporate culture interaction between the home country's executive officers and the host country's mid-management and workers.

Foreign Direct Investment (FDI)

The term FDI refers to an investment made to acquire lasting interest in enterprises operating outside of the economy of the investor (Balance of Payments Manual: Fifth Edition, 1993). The country of the investor is known as the home country, and the country where the enterprise operates is known as the host country (Kenwood \& Lougheed, 1999). A direct investment enterprise is an incorporated or unincorporated enterprise in which a single foreign investor owns $10 \%$ or more of the ordinary shares or voting power of an enterprise. The most important characteristic of FDI, which distinguishes it from foreign portfolio investment, is that it is undertaken with the intention of exercising control over an enterprise (Detailed Benchmark Definition of FDI: Third Edition, 1996). The components of FDI are equity capital (assets minus liabilities), reinvested earnings, and other capital (mainly intra-company loans). This measure of its 
static aspect is known as FDI stock. As FDI, however, is an interaction between

countries, the movement of capital from one country to another is also quantified. This measure of its dynamic aspect is known as FDI flows.

For the investor's home country this movement would be FDI outflows, and for the enterprise host country it would be FDI inflows. It is this last measure (FDI inflows) which the UNCTAD uses to calculate the Inward FDI Performance Index that is used in this study. This index ranks countries by the FDI they receive relative to their economic size. The Inward FDI Performance Index is the ratio of a country's share in global FDI inflows to its share in global Gross Domestic Product (GDP).

\section{Methods}

A multiple linear regression equation was completed to support with statistical significance the answers to the research question: Does higher education contribute to economic development in the context of globalization?

The information for the analysis was obtained from historical data of 91 countries. To be included, the data had to contain the Inward Foreign Direct Investment (FDI) Performance Index, the Human Development Index (HDI), and the Barro-Lee educational attainment dataset indicators. The period of time analyzed was 10 years, from 1990 to 2000 , but the data of some lagged variable covered 15 years back, from 1975 to 1990.

Model

The model derives from an equation of economic growth. I began with the simplest of economic growth models: the Cobb-Douglas production function (Cobb \& Douglas, 1928). This model specifies that economic growth is a function of physical 
capital, labor, and technology. To this initial simple specification, a variation of a component of the now accepted Solow model (Solow, 1956) was added: productivity (output labor ratio).

This model measures not only economic growth, but economic development as well or, in other words, sustained economic growth. The dependent variable is still economic growth, the main component of economic development, but the value of economic development, included in the model as a variable, is a composite index of human development. The measure of economic development is then the variance of economic growth explained by human development, which represents the means of constructing and maintaining an infrastructure that makes economic growth sustainable. The concept of economic development is very complex and debatable, and there is no consensus among researchers about which variables better explain it. The reasons why I have chosen human development as the measure of economic development is because human development implies a necessary condition of economic development.

As this study analyzes the contribution of higher education to economic development in a globalized environment, a variable that measures globalization was also added. The presence of foreign capital in a country is the most direct integration of that country into the world economy. Some of the reasons are the interaction with different corporate cultures, management styles, and technologies, which make the host country a more active participant in the global economy. Therefore, globalization in this study measures the change in the UNCTAD's Inward FDI Performance Index. The higher that index, the more globalized the economy of a country will be. 
This is a comparative static model which is the change of economic growth predicated on the change of other factors that is of interest, and two equations were run and compared. Each equation, one with a higher education and globalization interactive term and the other without it, produced different $R^{2}$ values. Since $R^{2}$ represents the amount of variance of economic growth explained by the model, the difference in $R^{2} s$ estimated the amount of variance explained (or, added) by the interaction of higher education and globalization. Additional regressions were run to expand the analysis. The independent effect of higher education and globalization on economic growth was compared with the effect of their interaction. Finally, the effect of secondary and higher education on economic growth in developed economies was compared with the same effect in less developed ones.

\section{Variables}

A total of 10 variables (the dependent and nine independent) are used in a comparative static model with the purpose of measuring the change of economic growth due to the change of other factors. All the variables, therefore, measured the change of the data between the beginning and the end of the period used for the analysis.

The dependent variable is per capita income (proportion of income to population) as the measure of economic growth, and the first four independent variables are components of generally accepted production functions: physical capital (the value of capital invested), labor (number of members of the workforce), technology (proportion of physical capital to labor), and productivity (the proportion of output to labor).

The next set of predictors comprises three variables, the three levels of formal education: primary, secondary, and tertiary. The values of these variables are completion 
at each corresponding level. The reason for choosing completion is to retain consistency between the measuring basis of the variables of education (number of graduates ready to work) and the variable of labor (number of members of the workforce). These variables are lagged to make their effect fit the timeframe of the period used in this study, which is based on the readiness of graduates to become active and productive members of the workforce.

The next variable is economic development. This variable measures the change in HDI, which is based on the UNDP's concept of human development. The HDI is a summary composite index that measures a country's average achievements in three basic aspects of human development: health, knowledge, and a decent standard of living (Human Development Reports - UNDP, n.d.). These aspects of human development are also necessary conditions of economic development.

The last variable of the model measures how much the economies under study are exposed to a globalized environment. This variable, globalization, measures the change in the UNCTAD Inward FDI Performance Index. This index ranks countries by the FDI they receive relative to their economic size and indicates the country's performance in attracting FDI.

Finally, in order to test for the interaction of higher education and globalization, the higher education variable and the globalization variable are combined into an interaction variable ${ }^{1}$. The goal is to discover to what extent the interaction of

\footnotetext{
${ }^{1}$ See McNeil, Newman and Kelly (1996) Testing Research Hypotheses with the General Linear Model. Especially see the Section entitled "Interaction between Two Continuous Predictors," pages 140-143.
} 
globalization and higher education is a statistically significant contributor to economic growth.

\section{Dissertation Outline}

In chapter 2 , the literature review explores the inclusion of formal education in economic growth and development analysis. The review chronologically examines how the study about the interaction of education with the economy has evolved up to the present. The chapter includes literature about higher education in economic growth and development models, human capital theory, and globalization.

The methodology is discussed in chapter 3. The chapter includes the research question, information about the data, and the limitations of the study. The model is explained in detail, the variables are defined, and the time period of the study is established. The chapter ends with a discussion about the data analysis procedure.

In chapter 4 , the answer to the research question is drawn from the model results, and the findings are discussed in chapter 5. This last chapter ends with conclusions about this study and recommendations concerning public policy, workforce development, and future research. 


\section{CHAPTER II \\ LITERATURE REVIEW}

Research related to higher education, globalization, and economic development are explored from different perspectives. The purpose of this review is to investigate to what extent the studies analyzed answer the following research question: Does higher education contribute to economic development in the context of globalization?

Higher education has been frequently used in economic growth models. It is also common to find economic growth analyzed within the context of globalization. Furthermore, there has been more concern about comprehensive economic development than mere economic growth. This literature review is chronologically organized so that the evolution of higher education as part of economic analysis can be followed from simple economic growth functions to more complex models that include globalization and economic development.

Any model designed to answer the above research question must include three main components: (a) higher education, (b) economic development, and (c) globalization. Of the literature researched, I present the studies most closely related to my research question. Agiomirgianakis, Asteriou, and Monastiriotis (2002), Keller (2006), Ramcharan (2004), and Vedder (2004) explicitly address higher education in their models. Agiomirgianakis et al., measure enrollment while Keller assesses spending per student, but they both include the other two levels of formal education (primary and secondary). Ramcharan also addresses higher education, but includes only one more level of education (secondary). Vedder includes only tertiary education, and his proxy is completion. With respect to globalization, the study of Makki and Somwaru (2004) is the 
most relevant to my research question, since they include FDI in their model. They, however, include only human capital stock and do not explicitly acknowledge higher education as an important element in the creation of that stock. In summary, these authors analyze how much higher education explains economic growth, or how much human capital and globalization explain economic growth. I have not found in the literature, however, any study specifically analyzing how much the interaction of higher education and globalization explain economic growth and development.

\section{Contribution to the Current Literature}

In addition to addressing higher education, my study also includes its antecedent levels (primary and secondary) as per Agiomirgianakis et al. (2002) and Keller (2006) but measures completion as in Vedder (2004). These variables measure not only the contribution of higher education to economic growth but also how different that contribution will be with the contribution of primary and secondary education levels. Globalization is addressed by including FDI in my model, as in Makki and Somwaru's (2004), but not trade. One of the advantages of FDI over trade is that it not only measures the contribution of globalization to economic growth but also the influence that the transfer of technology implicit in FDI may have on the level of technology of the host economy. Economic development is addressed in my model by including human development, which together with higher education will infer how much economic development explains economic growth.

The importance of my model and, therefore, the main contribution to the research community stems from two key aspects: that it analyzes how much the interaction of higher education with globalization explains economic growth, and that economic 
development is also measured. There is no economic development without economic growth. My model, like most economic models, analyzes how much economic growth is explained by its predictors. This model, however, also include a variable of economic development.

The results of this model support the assumption that the contribution of the interaction of higher education and globalization to economic growth is not substantial. These findings, however, suggest that both secondary and higher education do contribute to economic growth, mainly in less developed economies. My interest in this model, therefore, is that its results could motivate decision-makers in less developed countries. The implementation of public policy leading to the promotion and expansion of education could help in the achievement of economic development.

\section{The Production Function and Economic Growth}

Most econometric models of economic growth have been based on the CobbDouglas production function. It specified that economic growth was a function of physical capital, labor, and technology (Cobb \& Douglas, 1928). This model has been tested in many different scenarios, and some researchers have enhanced it. To this initial and simple specification, two components were added by Harrod (1948) and Domar (1957): savings and productivity of investment (capital output ratio). After Domar's contribution, it was known as the Harrod-Domar model. This model has been used in the analysis of development economics to explain economic growth in terms of the level of saving and productivity of capital. It has implied that to achieve economic growth the level of investment must be expanded both in terms of physical capital and human capital. To do this, policies should be implemented to encourage savings and generate 
technological advances that enable firms to produce more output with less capital (i.e., lower their capital output ratio). Later, this model was tested and extended by Solow (1956). He made it dynamic and treated technological growth and savings as exogenous variables (determined outside the system). The model became what is now known as the Solow model. This new version of measuring economic growth has allowed for the inclusion of more variables (exogenous) in the models, including human capital and more specifically, education.

\section{Economic Development}

Economic growth alone has not guaranteed the human well-being of a society. The terms "economic development" and "economic growth" has sometimes been used interchangeably when referring to economic growth. Economic growth has actually been the expansion of a country's potential national output or real GDP: the expansion of the economic power to produce (Samuelson \& Nordhaus, 1985). On the other hand, economic development has been a much broader concept. It has been assumed to be the construction and maintenance of an infrastructure that has made economic growth sustainable. For Myrdal (1974), economic development meant the movement upward of the entire social system. He argued that this social system enclosed, besides the so called economic factors, all non economic factors. He referred to these factors as, among others, all sorts of consumption by various groups of people, consumption provided collectively, educational and health facilities, and distribution of power in society.

One of the reasons why economic development has become the center of attention of many researchers has been the striking difference between more developed countries and less developed countries (LDC). Three main theories have been tailored around the 
concept of economic development based on the difference between those two categories of countries in the world. Under the theory of development as growth and physical capital formation, LDCs were seen mostly as "primitive" versions of developed nations that could, with time, "develop" the institutions and standards of living of their more developed counterparts. Rostow (1990) argued that all countries passed through the same historical stages of economic development, and that current underdeveloped countries were merely at an earlier stage in this linear historical progress, while more developed nations were at a later stage.

The second theory was concerned with the social aspects of economic development. Based on this theory, Schultz (2003) turned away from physical capital accumulation to human capital formation. He emphasized education and training as prerequisites of growth. For Seers (1997), development was a social phenomenon that involved more than increasing per capita output but also the elimination of poverty, unemployment, and inequality.

Structuralism, the third theory, called attention to the distinct structural problems of LDC, considering that they were not merely "primitive versions" of developed countries, but that they had distinctive features of their own. Based on this theory, Hirschmann (1958) stressed the need for country-specific analysis of development, while Singer (1989) and Prebisch (1988) agreed with the famous "dependency" theory of economic development. They both argued that the world had developed into a "centerperiphery" relationship among nations, where LDC were regressing into becoming the producer of raw materials for developed manufacturer countries and were thus condemned to a peripheral and dependent role in the world economy. 


\section{Human Capital and Economic Growth}

The production function models built with endogenous variables to measure economic growth have evolved into more complex models. These later models have included exogenous variables and have been intended to explore not only economic growth but economic development as well. One of those variables has been human capital. According to Schultz (1961) and Becker (1964), the fundamental postulate of human capital theory was that increases in schooling were responses to an increased demand for skilled labor. Thus, individuals continued to pursue higher levels of education until the opportunity cost of acquiring more education was greater than the benefit that it provided. From another perspective, human capital theory held that the well-being of a modern society was dependent not only on traditional concepts of capital and labor but also on the knowledge and ideas possessed and generated by individual workers. Furthermore, education was assumed to be the primary source of this human capital. An educational productivity model, therefore, was based on the assumption that the goal of educational policy was not just to provide services but to produce outcomes that could contribute to the development of human capital (Crocker, 2002).

In another association of education with human capital, Walters (2004) argued that education was a form of human capital that had been most widely discussed in the literature. He added that proponents of human capital theory asserted that schools were developed to prepare people for modern roles that were not addressed by the more traditional agents of socialization, such as the family or the church. For Walters, education was assumed to provide students with skills they could bring to their jobs, and it also allowed them to be more productive and functional members of society. Citing 
Hunter (1988), he agreed that education represented a major means through which individuals acquired the mental skills and capacities for self-direction necessary for successful future performance in the workplace.

Human capital has comprised skills with specific industrial application possessed by an individual. These skills could be acquired through, among other things, generational transfer of information, on-the-job training, seminars, workshops, and formal education. It has been common to find formal education, and more specifically higher education, as a proxy for human capital in economic growth models. Galindo Martin and Alvarez Herranz (2004), however, included human capital in their model, not using education as a proxy for it, but instead using its own value as a measure of productive capacity. Their model's dependent variable was regional GDP, and the main independent variables were private investment, public investment, and per capita productive human capital. They analyzed the technological role of human capital, as well as the effects of human capital on the economic growth process. Specifically, their study estimated a model that explained the Spanish regions' growth process during the period between 1995 and 2000. In such analysis, the paper introduced human capital behavior to show the relationship between human capital investment and regional economic growth on the rate of productivity and income of the regions.

An interesting aspect of that study was the assumption that, as stated above, the formation of an individual's human capital did not depend solely on his or her education level but also on other learning factors. Accordingly, informal learning may have been more important than the education received in the institutional system. For that reason, the productive human capacity of each person was measured as a function of the number 
of workers' equivalent without human capital that was necessary to reach that person's productive capacity (Galindo Martin \& Alvarez Herranz, 2004).

After completing their analysis, Galindo Martin and Alvarez Herranz (2004) concluded that human capital was an important factor that improved the economic growth in the regions of Spain, and recommended that economic policies had to be designed to improve the educational levels. This recommendation showed the authors' position with respect to the important role of formal education in economic growth. The final results showed a statistically significant relationship between human capital and economic growth. That study, however, was circumscribed to particular regions of the Spanish economy and did not prove that the same relationship would have existed in a national or the global economy. Finally, the broad use of human capital may have disguised some important schooling effects. Even though the role of technology was considered in the process of economic growth, their study did not identify the effect of higher education in the development of technology.

The relationship between education and economic growth has been explored over many years. Empirical evidence developed by many scholars, among them Denison (1961), Mowery and Rosenberg (1989), Benhabib and Spiegel (1992), Mankiw, Romer, and Weil (1992), and Agiomirgianakis et al. (2002) has confirmed the importance of education to economic growth. In their research analyzing the relationship between human capital and economic growth, Agiomirgianakis et al. used formal education, emphasizing higher education, as the proxy for human capital. In their study, therefore, the only effect of human capital on economic growth was the effect of education. They approached the issue by focusing on less explored economies. The last two decades have 
witnessed voluminous empirical studies worldwide that have tried to investigate quantitatively the relation between education and economic growth. The general result of these studies has indicated that there has been a positive correlation between economic growth and education. Agiomirgianakis et al., however, argue that many of the existing studies on the relationship between education and economic growth have been carried out by employing cross-sectional data and techniques mostly from the advanced countries that had solved their most crucial problems of development by the first quarter of the 20 th century. In their empirical analysis, panel data was employed using dynamic panel data techniques for a diverse set of 93 countries over a period of 28 years, with different levels of economic development and different trends in terms of GDP growth. The dependent variable of their model was per capita GDP, while the main predictors were per capita physical capital and primary, secondary, and tertiary education enrollment.

Agiomirgianakis et al.'s (2002) findings not only suggested the existence of a robust positive relationship between education and economic growth, but also that higher levels of education had a stronger effect on economic growth. The policy implication of this result was that governments were inclined to adopt measures that expanded higher education in their countries in order to increase potential gains in term of a higher economic growth. Therefore, their findings had a straightforward policy implication that governments taking actions towards an expansion of their higher education may have well expected larger gains in terms of higher economic growth in their countries. Moreover, as Agiomirgianakis et al. analyzed data of a large number of countries, their findings may have also contributed towards an explanation of the observed expansion of higher education in several countries. This work not only showed evidence of the effect 
of education on economic growth but also that the higher the level of education the higher its effect on growth was. Consequently, this evidence was a strong tool to stimulate policy-making in favor of higher education. It is a pity, however, that globalization was not included in the analysis.

Another example of the explicit use of education as the proxy for human capital was the investigation conducted by Keller (2006) about the effects of primary, secondary, and higher education on per capita growth (dependent variable). The measures of the model were per capita GDP growth rate as the dependent variable, and as independent variables, enrollment rates and primary, secondary, and tertiary public expenditures per student. As a conclusion, Keller stated that while the importance of human capital to economic growth was a part of standard economic theory, exactly how education should have been expanded was little researched (a statement with which I agree). Globally, according to the results, countries raising enrollment rates in secondary and higher education have grown faster during the period studied (1960-2000), as well as those that have spent more public expenditures per student in primary and secondary education and more in general on primary education. In the face of scarce resources, public resources appeared better allocated toward basic education rather than higher education, while encouraging private resources via government loans financing college attendance seemed beneficial.

Keller's (2006) study showed an adequate and updated approach to the analysis of the effect of higher education and education in general on economic growth. The selected variables were consistent with the objective of the study and very interactive. However, considering that Keller's study was so global that it included data from a large number of 
developed and developing countries, and that part of the period analyzed (1960-2000) includes an era of globalization development through the noticeable expansion of multinational corporations in the 1990s (Sauvant, 2003), the results would have been more accurate if globalization had been included in the analysis.

\section{Education as a Capital Good}

Human capital has played different roles in economic models to the extent that an analogy has been established between it and physical capital, considering both as capital goods. The reason has been that in those models human capital has functioned with similar behaviors and characteristics as any other capital good. Examples have been cases in which researchers have found human capital involved in situations of depreciation, sunk costs, externalities, and crowding-out effect. The following literature not only presents other ways to approach human capital and education but also exemplifies the above situations.

Depreciation, also known as capital consumption allowances, has been the value of the capital that has worn out during the period over which economic activity was being measured (Abel \& Bernanke, 1995). In other words, depreciation has been the consumption of capital goods. Human capital has been depreciating during its interaction with technology. The knowledge and skills possessed by the workforce at a particular level of technology has become obsolete when the level of technology has been increased. Depreciated physical capital has been upgraded with maintenance, repairs, or major replacement investments. Depreciated human capital has been upgraded by retraining current workforce members or by the incorporation of new members possessing new knowledge and skills. 
An example of human capital depreciation could be seen in an article written by Fedderke (2002). When analyzing the effect of human capital on economic growth, he included in his model technology, physical capital, labor, productivity, and research and development (R\&D). Also, he cited Shell (1966) referring to the concept of depreciation of knowledge, and agreed that technological progress depended on the amount of resources devoted to inventive activity. Fedderke argued that the change in technology per unit of time was positively affected by the resources devoted to knowledge creation, while knowledge was subject to depreciation, as old forms of technology face obsolescence. According to this assumption, human capital was the stock of knowledge of the labor force, and as knowledge depreciated human capital depreciated. An economic effect of knowledge obsolescence has been the structural unemployment. According to Samuelson and Nordhaus (1985), this type of unemployment has occurred when there was a mismatch between the supply of and the demand for workers. Samuelson and Nordhaus added that mismatches could occur because the demand for labor of one kind was rising, while the demand for another kind was falling and supply did not quickly adjust.

With the constant increase of the level of technology, the demand for labor matching the old technology has decreased while the demand for labor matching the new technology has increased. Therefore, the labor force unemployed because of obsolete knowledge would have represented the human capital depreciation. If this out-of-fashion knowledge were not replaced with new knowledge, the structural unemployment in that setting would have grown for ever. In that situation, formal education would have been the main producer of new knowledge necessary to restore the part of the human capital 
that had been depreciated. From this perspective, the production of education should have been great enough to keep an adequate level of updated human capital to reduce the structural unemployment and keep a steady level of economic growth.

In their analysis of regional convergence of different growth models based on endogenous theory, Martin and Sunley (1998) examined the effect of externalities, together with human capital and technology, to explain changes in per capita GDP. Endogenous growth theory has been based on the existence of positive externalities and increasing returns. There has been, of course, a long tradition of using externalities and increasing returns in urban and regional analysis, a tradition that has been revived in recent years. Usually, it has been assumed that externalities and spillovers have been perfectly mobile within national industries and sectors, even between different nations. Externalities have included the ability of local communities to provide financial resources for education and the series of rules, norms, and peer effects described as "social capital." In this view, investment in human capital has been a local public good. Also, neighborhood spillover effects have transmitted economic status from one generation to the next (Martin \& Sunley, 1998).

Martin and Sunley (1998) have highlighted an important aspect about the importance of developing human capital to guarantee economic growth. The reason is, for instance, that even though we could measure the value of human capital from the resources allocated to higher education, the true value of it could be underestimated. The interaction of the highly qualified labor force among different disciplines of knowledge in the work place could enrich human capital. It could be assumed that this knowledge spillover has acted as a multiplier within human capital, increasing its quantitative and 
qualitative potential in the production process of the economy. The concept of externalities leads to a stronger understanding of the relationship between human capital and economic growth.

Usually, costs could have been recovered when they were incurred for capital that could have easily been sold or put to alternative use. An airline company could always use its planes on alternate routes or sell planes if leaving the industry. However, sunk costs have been those that could have not been recovered. A railroad company could not easily tear up its tracks and use them elsewhere without incurring heavy losses. Additionally, there would not be much of a market for used rails and ties. Therefore, it would be less expensive for the company to leave the tracks and ties "sunk" in the ground (Hyman, 1986). The existence of sunk costs in human capital has been a consequence of its depreciation (discussed above). Typically, the current human capital used in the production process has suited the actual level of technology. Once the level of technology was increased, the current human capital depreciated. The currently useless knowledge and skills could not be sold or put to alternative use. Consequently, the costs incurred in developing the no longer useful human capital were unrecoverable, sunk costs.

Ramcharan (2004) introduced the concept of sunk costs in one of his studies. He analyzed the effect of education on economic growth (GDP) from the perspective of two education levels (secondary and tertiary), which corresponded to two levels of human capital (unskilled and skilled) that he also included in his model. Ramcharan associated secondary schooling with unskilled human capital and higher education with skilled human capital with the purpose of analyzing the worthiness of costs incurred by investing in higher education. According to him, the composition of human capital stock 
determined a country's development. Based on that assumption, Ramcharan argued that developing economies need only invest in secondary schooling, importing high-skilled education embodied in the foreign good. Hence, promoting the "wrong" type of schooling could have little effect on development and brain drain could occur.

Did all types of human capital affect growth identically? Did the impact of a particular type of human capital on growth depend on the presence of other types of human capital? What were the characteristics of an optimal education policy? To address these questions, Ramcharan developed a simple analytic framework that emphasized the role of the composition of the human capital stock. The framework relied on two key assumptions. First, it assumed that each skill type performed a specific but complementary function within the production process in the skilled sector, creating demand linkages between the education types that are external to the firm. Second, the paper studied those demand linkages within the context of endogenous schooling costs.

Based on this analysis of the composition of the workforce, Ramcharan (2004) assumed that education investment was irreversible, because the investment process was sequential and individuals incurred a unique fixed cost (sunk cost) at each step in the educational ladder. Ramcharan added that the size of this sunk cost depended on an individual's personal characteristics, such as preferences, family background, and intrinsic ability, as well as policy variables, such as the development of the education infrastructure (e.g., distance from home to school, the quality of instruction, and the nature of the curriculum). He assumed that these personal characteristics and policy variables were uncorrelated with future productivity. 
If human capital was a determinant factor of economic growth, all the resources allocated to higher education as the main producer of human capital were assumed to be justifiable to guarantee economic growth. However, as Vedder (2004) argued, that was not always the case. To support his assumption, he introduced the economic concept of crowding-out effect in his analysis. For that purpose, he developed a model where initial income, change in taxes, state and local government higher education spending, and population with a college level education explained changes in per capita personal income. When increased government expenditures have caused investment to decline, economists have said that investment has been crowded out. The crowding-out of investment by increased government expenditures has occurred, in effect, because the government was using more real resources, some of which would otherwise have gone into private investment (Abel \& Bernanke, 1995).

In his analysis, Vedder (2004) found that the empirical evidence suggested that despite the higher and increasing relative productivity of college graduates, state funding for higher education had negative effects on economic growth. He added that the return on additional public higher education investment may have diminished over time to become less than obtainable with other uses of funds, either for public or private investment, because graduates would have produced less value than the value of the resources invested in their education. If so, incremental spending on public higher education might actually have lowered economic growth by crowding out more productive alternative uses of the resources. Vedder cited Hoxby (1999) when referring to higher education productivity. Hoxby argued that although difficult to measure, productivity was probably falling in higher education, consistent with the experience in 
primary and secondary public schools. Thus, increased higher education spending meant allocating funds away from the private sector, with rising (and probably higher initial) productivity, to a sector with falling productivity. For Vedder, much of the rise in enrollment-adjusted staffing had come not in faculty (instruction), but in other forms, especially "other professional" employees: administrators, secretaries, computer programmers, student activity personnel, affirmative action officers, football coaches, and so forth. He added that the ratio of "executive/administrative/managerial" workers to students in universities had risen $20 \%$ in two decades in the late $20^{\text {th }}$ century. Vedder argued that these people did not contribute much directly to adding to human capital.

Considering the crowding-out effect in the relationship between human capital and economic growth was important. Any economic action associated with economic policies, could have a (often undesirable) side effect, and the crowding-out effect was one of them. This empirical evidence alerted policymakers to consider that not always does "much" means "better" when allocating resources. The issue was not to stop allocating resources to higher education to avoid the crowding-out effect but to allocate those resources efficiently. I disagree with Vedder (2004), however, in assuming that these people (when referring to non-instructional employees) did not contribute much directly to adding to human capital. No higher education institution could operate without noninstructional employees. Therefore, the resources allocated to operate these institutions were part of the social cost of producing human capital and were supposed to be added to it. When the created human capital (with the non-instructional expenditures included) was used in the private sector, the economic growth that it created could have 
compensated, and even surpassed, the initial decrease in growth that those expenditures caused when the human capital was created.

\section{Human Capital in a Globalized Context}

The development of globalization in recent years has created concerns among researchers in many areas of interest, and the area of education has not been an exception (Torres, 2002). Therefore, some studies have included FDI and international trade as proxies for globalization in economic growth models together with human capital. The purpose has been not only to measure the impact of these variables on economic growth but to determine the interaction between globalization and human capital as well. According to Makki and Somwaru (2004), FDI and trade have been often seen as important catalysts for economic growth in developing countries. With respect to FDI, they have considered it an important vehicle of technology transfer from developed to developing countries, and also have considered that it has stimulated domestic investment and facilitated improvements in human capital and institutions in the host countries.

On the international trade side, they added that it has been also known to be an instrument of economic growth, since it has facilitated more efficient production of goods and services by shifting production to countries that have had comparative advantage in producing those goods and services. The econometric model designed by Makki and Somwaru was derived from a production function in which the level of a country's productivity depended on FDI, trade, domestic investment, human capital, and initial GDP per capita. The model was based on endogenous growth theory in which FDI contributed to economic growth directly through new technologies and other inputs as well as indirectly through improving human capital, infrastructure, and institutions. Also, 
FDI helps keep the balance between supply of and demand for higher education. If there is a surplus of higher education, brain drain could also occur.

One of the regressions of this study revealed that FDI and trade had a positive impact on economic growth after controlling for human capital, domestic investment, and initial income. The estimated coefficient of FDI was positive and statistically significant while the estimated coefficient of trade was not statistically significant. Since the coefficient of FDI was larger than the coefficient of trade, it indicated the differential impact of FDI in the host country's economic growth. Additionally, the coefficient for human capital was positive, implying that human capital contributed positively to economic growth (Makki \& Somwaru, 2004).

One of the important questions raised in the literature was whether FDI augmented a host country's capital investment or crowded out domestic investment. In their study, even though not statistically significant, the positive interaction between FDI and domestic investment in regression implied that domestic investment was unlikely to be crowded out in developing countries (Makki \& Somwaru, 2004). This may have been because of the fact that FDI in the form of large multinational corporations could have increased the demand for outsourcing goods and services provided by local smaller businesses, as has been seen in large domestic corporations. This may have implied an additional increase in the demand for investment in human capital and, consequently, a further expansion of higher education. Makki and Somwaru also found a positive interaction between FDI and human capital in advancing economic growth. This implied that the application of advanced technology embodied in FDI required a sufficient level 
of human capital in host countries. That is to say, the higher the levels of human capital in a host country, the higher the effect of FDI on the country's economic growth.

The results of Makki and Somwaru's (2004) study are relevant to my research question because the authors concluded that human capital and FDI not only positively contributed to economic growth, but that the contribution of FDI to economic growth was directly related to the level of human capital. I criticize, however, two aspects of the model. First, the variable corresponding to human capital was only the value of the human capital stock, and higher education was not recognized as part of the formation of that stock. Inflows of FDI have implied the development of high technology, and higher education has been assumed to be fundamental in the formation of the highly qualified human capital stock required in the global environment. Finally, the dependent variable of the model, which represented the level of a country's productivity, was the per capita GDP growth rate (Makki \& Somwaru, 2004). In economic terms, a country's productivity has referred to the amount of output (GDP) that each worker produces, whereas per capita GDP has been an indicator of how much output the average person would get if all output were divided evenly among the population (Schiller, 2000). Therefore, the use of the rate of output per unit of labor as the independent variable would have allowed the model to provide more accurate results.

\section{Summary of the Literature Review}

The models in the above studies explained the role of human capital in economic growth from different perspectives. Table 1 summarizes the eight models examined and classifies them according to their main characteristics. For Galindo Martin and Alvarez Herranz (2004) education was not included as a proxy for human capital. Therefore, no 


\section{Table 1}

Models Analyzed in the Literature Reviewed

\begin{tabular}{|c|c|c|}
\hline Main Model Characteristic and Author & Dependent Variable & Main Independent Variables \\
\hline \multicolumn{3}{|l|}{ Human Capital as a Variable } \\
\hline $\begin{array}{l}\text { Galindo Martin and Alvarez Herranz } \\
\text { (2004) }\end{array}$ & Regional GDP & $\begin{array}{l}\text { Private Investment } \\
\text { Public Investment } \\
\text { Per Capita Productive Human Cap }\end{array}$ \\
\hline \multicolumn{3}{|l|}{ Education as a Proxy for Human Capital } \\
\hline $\begin{array}{l}\text { Agiomirgianakis, Asteriou, } \\
\text { and Monastiriotis, (2002) }\end{array}$ & Per Capita GDP & $\begin{array}{l}\text { Physical Capital per Capita } \\
\text { Three levels of Ed Enrollment }\end{array}$ \\
\hline Keller (2006) & $\begin{array}{l}\text { Per Capita GDP } \\
\text { Growth Rate }\end{array}$ & $\begin{array}{l}\text { Primary Ed Spending per Student } \\
\text { Secondary Ed Spending per Student } \\
\text { Tertiary Ed Spending per Student } \\
\text { Enrollment Rates }\end{array}$ \\
\hline \multicolumn{3}{|l|}{ Education as a Capital Good } \\
\hline Fedderke (2002) & GDP & $\begin{array}{l}\text { Physical Capital } \\
\text { Labor } \\
\text { Technology } \\
\text { Productivity } \\
\text { Human Capital } \\
\text { Research and Development (R\&D) }\end{array}$ \\
\hline Martin and Sunley (1998) & Per Capita GDP & $\begin{array}{l}\text { Technology } \\
\text { Human Capital } \\
\text { Externalities }\end{array}$ \\
\hline Ramcharan (2004) & GDP & $\begin{array}{l}\text { Secondary Education } \\
\text { Tertiary Education } \\
\text { Unskilled human capital } \\
\text { Skilled Human Capital }\end{array}$ \\
\hline Vedder (2004) & $\begin{array}{l}\text { Per Capita Personal } \\
\text { Income }\end{array}$ & $\begin{array}{l}\text { Initial Income } \\
\text { Change in Taxes } \\
\text { State \& Local Gov Higher Ed Spend } \\
\text { Population with College Level }\end{array}$ \\
\hline $\begin{array}{l}\text { Human Cap in a Globalized Context } \\
\text { Makki and Somwaru (2004) }\end{array}$ & $\begin{array}{l}\text { Productivity } \\
\text { (Per capita GDP } \\
\text { growth rate) }\end{array}$ & $\begin{array}{l}\text { Initial Per Capita GDP } \\
\text { Domestic Investment } \\
\text { Human Capital } \\
\text { International Trade } \\
\text { Foreign Direct Investment (FDI) }\end{array}$ \\
\hline
\end{tabular}


part of the regional output was explicitly explained by formal education. Many models, however, considered education as the main source of human capital development and included it as a proxy for human capital. The proxy used by Agiomirgianakis et al. (2002) was the enrollment in the three levels of formal education (primary, secondary, and tertiary). Keller (2006) also explicitly used the three levels of education as proxies for human capital but to measure spending per student.

The increasing interest in exploring the contribution of human capital to economic growth has made research go even further. Human capital has been considered as a regular capital good and treated as such. Fedderke (2002) analyzed the depreciation of human capital as the obsolescence of knowledge due to changes in technology. Martin and Sunley (1998) argued that the interaction of the highly qualified labor force among different disciplines of knowledge in the work place produced externalities that could enrich human capital. A consequence of human capital depreciation has been the existence of sunk costs. Ramcharan (2004) argued that the currently useless knowledge and skills could not be sold or put to alternative use, becoming a sunk cost. The effect of human capital has been also examined within the public sector. Vedder (2004) used state and local government higher education spending as the proxy for human capital. $\mathrm{He}$ argued that incremental spending on public higher education might actually lower economic growth by crowding out more productive alternative uses of the resources. Finally, the last model analyzed explored the interaction of human capital and economic growth within the context of globalization. Makki and Somwaru (2004) used international trade and FDI as the proxies for globalization. An important aspect in their model was that its results not only supported the assumption that human capital and FDI 
positively contributed to economic growth, but also that the level of FDI contribution to economic growth was directly related to the level of human capital. Globalization has become so socially and economically pervasive that the exclusion of it in economic models could compromise the accuracy of the results. The next chapter presents in detail the main characteristics of my model as well as the way that its variables address the contribution of higher education to economic development within a globalized context. 


\section{CHAPTER III}

\section{METHODS}

Research Question

A multiple linear regression model was designed, built, and run to estimate and test causal relationships with the purpose of supporting the answer to the following research question: Does higher education contribute to economic development in the context of globalization?

\section{Data}

A total of 91 countries were selected for this study. The selection was the result of merging the 1955-2000 Barro-Lee Education Attainment Dataset of 142 countries (Barro \& Lee, 2001), the UNCTAD Inward FDI Performance Index dataset of 140 countries (UNCTAD.ORG FDI Indices, n.d.), and the UNDP Human Development Index dataset of 177 countries (Statistics - Human Development Reports [UNDP], n.d.). Initially, a total of 94 countries that had information in the datasets referenced above overlapped. Three of these countries (Myanmar, Sierra Leone, and Taiwan), however, were dropped for lack of information (see Appendixes A to D for complete lists of countries).

The remaining data analyzed in this study were obtained from the following sources: UN Statistics Division per Capita GNI and Gross Fixed Capital Formation databases (United Nations Statistics Division - National Accounts, n.d.), UNCTAD Statistics Handbook 2008 Labor Force Table (Beyond 20/20 WDS - Report Folders, n.d.), and the IMF World Economic Outlook GDP Database (World Economic Outlook Database October 2008, n.d.). 


\section{Limitations}

The information measured by all the variables of this model is available for all the countries included in this analysis. A limitation of this study, however, prevented the inclusion of few more countries. This limitation was the missing data in time series. This is a common problem when international data analysis includes poor countries with sporadic data. Only few incomplete time series were chosen because enough information was available to estimate the data. According to each particular situation, a decision was made either to delete the whole case or apply a suitable data imputation procedure. Any course of action was followed preventing biases and avoiding compromising the statistical power of the analysis. This limitation, however, did not diminish significantly the validity of the results since the number of countries analyzed was still considerably large.

\section{Model}

Analyzing higher education as a source of human capital whose only purpose is to assure economic growth will obscure the main reason of schooling. With this assumption, higher education, or formal education in general, is seen as a mere market tool. In my opinion, analyzing education as a source of economic development should take into consideration all the effects of schooling. From this perspective, education is still the producer of an economic product, but also serves as the producer of a sub product that contributes to the sustainability of economic development: intellectual development of individuals. Consequently, this economic sub-product has also social connotations for individuals that include, among other things: (a) more access to the total economic 
output, (b) lifestyle improvement, and (c) decline in the manifestation of criminal and delinquent behavior.

As the purpose of this analysis is not only to find the contribution of education to economic growth in a globalized environment, but also to find it within the whole context of sustainable economic development, the model of this study includes an economic development variable. For this purpose, the value of this variable of economic development measures the changes of a comprehensive human development index that includes aspects that constitute necessary conditions to achieving economic development. The Production Function

The model derives from a model of economic growth. I begin with the simplest of economic growth models, the Cobb-Douglas production function (Cobb \& Douglas, 1928). This model specifies that economic growth is a function of physical capital, labor, and technology. That is:

$$
y=f k^{\alpha}, l^{\beta}, a
$$

Where:

$\mathrm{y}=$ total production in the economy

$\mathrm{k}=$ physical capital formation in the country

$1=$ number of people in the labor force

a, $\alpha, \beta$ are constants determined by technology

In this equation, $\alpha$ and $\beta$ are constants determined by a particular technology, and they are used to represent production processes experiencing increasing $(\alpha+\beta>1)$, decreasing $(\alpha+\beta<1)$, or constant $(\alpha+\beta=1)$ economies of scale. In this study, technology is not constant and the inclusion of economies of scale is not necessary. As 
these components are not relevant in this study, I dropped the exponents and used only the linear version of the function, which becomes:

$$
y=f k, l, a
$$

This model also measures how much technology is affected by different levels of higher education. Therefore, a variable of technology $(t)$, which measures the proportion of physical capital per member of the workforce used in the production process, is substituted in the model for the Cobb-Douglas technology constant (a), becoming:

$$
y=f k, l, t
$$

Where:

$\mathrm{t}=$ technology - the proportion of physical capital to labor. This is a measure of how much physical capital is used in the production process for each unit of labor used in it.

It adds to this initial simple specification two components of the now accepted Solow model: savings and productivity (Solow, 1956). Using the Cobb-Douglas model as the basis for their analysis, this model was first developed by Harrod (1948) and later by Domar (1957). After Domar's contribution, it was known as the Harrod-Domar model. Later, this model was tested and extended by Solow, becoming what is now known as the Solow model. As in an economic condition of equilibrium savings equal investments, and as investment is included as an addition in the physical capital, savings will not be included. The new variable added is then productivity $(p)$, which makes the model become:

$$
y=f k, l, t, p
$$


Where:

$\mathrm{p}=$ productivity - the proportion of output to labor. This is a measure of how much output is produced by one unit of labor.

\section{Education Components}

The main purpose of this study is to measure the variance of economic growth explained by higher education. It is important, however, to control for other variances of economic growth that could be explained by other levels of formal education. For that purpose, a variable of education $(e d)$ split among its three corresponding levels (primary, secondary, and tertiary) is added to the model, which becomes:

$$
y=f k, l, t, p, e d
$$

Where:

ed $=$ education - the three levels of formal education.

\section{Economic Development Component}

This model is assumed to measure not only economic growth, but economic development as well, or in other words, sustained economic growth. Therefore, a variable of economic development is included in the model. This variable measures the change in a human development index that includes necessary conditions of economic development. The new variable added is then economic development ( $h d i)$ and the model becomes:

$y=f k, l, t, p, e d, h d i$

Where:

hdi $=$ a measure of human development. This is the Human Development Index (Human Development Reports -UNDP, n.d.) which measures a variety of social 
development characteristics of a country and norms them into a cohesive index in

which 0 equals no human development and 1 equals perfect human development.

\section{Globalization Component}

Finally, as this study analyzes the contribution of higher education to economic development in a globalized environment, a variable that measures globalization is also added. From an economic viewpoint, FDI is one the main manifestations of globalization. The presence of foreign capital in a country is thought to be the most direct integration into the world economy, mainly because of the multifaceted interaction between the home and host countries. Therefore, FDI is assumed to be the variable that best represents the globalization of a domestic economy. For that reason, a variable for FDI $(f d i)$ is added to the model, which becomes:

$$
y=f k, l, t, p, e d, h d i, f d i
$$

Where:

$\mathrm{fdi}=\mathrm{a}$ measure of globalization. This is the proportion of foreign direct investment to gross national product - a measure of how much the economy is linked to the outside investment (UNCTAD.ORG FDI Indices, n.d.).

Conceptually, the specification is linear:

$$
y=k+l+t+p+e d+h d i+f d i
$$

To encompass the dissertation question of whether globalization interacts with education to increase economic development, it was necessary to add a concomitant interaction term:

$$
y=k+l+t+p+e d+h d i+f d i+h e^{*} f d i
$$


Where:

he $=$ the value of the education variable (ed) corresponding to higher education.

The interaction term attempts to model whether higher education has an effect on economic growth when it interacts with globalization.

Finally, the model is comparative static such that it is the change of economic growth predicated on the change of other factors that is of interest. The model becomes:

$$
\Delta y=\Delta k+\Delta l+\Delta t+\Delta p+\Delta e d+\Delta h d i+\Delta f d i+\Delta h e^{*} \Delta f d i
$$

The research question asks whether the interactive effect of higher education and globalization have a substantial effect on economic development. Thus, two equations were run and compared:

$$
\begin{aligned}
& \text { (1) } \Delta y=\Delta k+\Delta l+\Delta t+\Delta p+\Delta e d+\Delta h d i+\Delta f d i+\Delta h e^{*} \Delta f d i \\
& \text { (2) } \Delta y=\Delta k+\Delta l+\Delta t+\Delta p+\Delta e d+\Delta h d i+\Delta f d i
\end{aligned}
$$

Each equation produced a different $R^{2}$ value. Since $R^{2}$ represents the amount of variance of economic growth explained by the model, the difference in $R^{2} s$ estimated the amount of variance explained (or, added) by the interaction of higher education and globalization.

\section{Time Period}

The total time span for the analysis was 10 years from 1990 to 2000 . The reason for choosing this period is the increase in capital flow in the world economy during those years. That increase was caused by the openness of many countries to foreign investments, such as China, India, less developed economy countries in Southeast Asia, transition economy countries in Eastern Europe, and the former Soviet Union republics (Kenwood \& Lougheed, 1999). The beginning of the period was determined by the year 
the UNCTAD started the calculation of the inward FDI performance index. Actually, according to the global capital flow behavior prior to that year, the inclusion of previous years' data would have caused no substantial effect on the results of this study.

With respect to the end of the period, it was determined by the last update of the educational attainment dataset that was used in this study (Barro \& Lee, 2001). In addition, the exclusion of more recent years decreases the probability of any negative effect that events such as the Asian financial crisis in 1997 (MacIntyre, 2001), the attack to the World Trade Center in 2001 (Maillet \& Michel, 2005), and the volatility of oil prices that started in 2003 (Mitchell, 2006) could have on the final outcome of the model. The levels of education variables, however, were lagged back up to 15 years, which made the data collection period expand up to 25 years-from 1975 to 2000 .

The restrictions of the time period are not supposed to compromise the statistical significance of this study. The model used is a multiple regression equation in which quality cause-effect information is combined with statistical data to provide quantitative assessment of cause-effect relationships among variables of interest (Pearl, 2000). This model is intended to estimate prediction accuracy and, therefore, it aims to hypothesis testing rather than theory development. The main purpose of this study is to determine whether the contribution of higher education to economic development when higher education interacts with globalization is statistically significant, regardless of the positive or negative effects that other events in the economy could have on this relationship.

\section{Variables}

A total of 10 variables ( 1 dependent variable and 9 linear independent variable predictors) are used in this model. These variables are summarized in Table 2. This is a 
Table 2

Summary of Variables

Variables

Measure

Period

Dependent Variable

Economic Growth $(y)$

Change in per capita income

$1990-2000$

Independent Variables

Derived from Cobb-Douglas

Physical Capital $(k)$

Change in physical capital

$1990-2000$

Labor $(l)$

Change in workforce

$1990-2000$

Technology $(t)$

Change in proportion of physical capital to labor

$1990-2000$

Derived from Solow Model

Productivity $(p)$

Change in proportion of output

$1990-2000$

Education (ed) to labor

Higher Education (he)

Change in higher education completion - 5-year lag

$1985-1995$

Secondary Education (se)

Change in secondary education completion - 10-year lag

$1980-1990$

Primary Education (pe)

Change in primary education completion-15-year lag

$1975-1985$

Economic Development

Economic Development ( $h d i)$ Change in Human Development Index

$1990-2000$

Global Environment

Globalization $(f d i)$

Change in Inward FDI

Performance Index

$1990-2000$ 
comparative static model with the purpose of measuring the change of economic growth due the change of other factors. All the variables, therefore, measure the difference of the data between the beginning and the end of the period used for the analysis.

\section{Dependent Variable}

The proxy for the dependent variable economic growth is the change in per capita income between the beginning and the end of the period of study. Measuring economic growth from changes in per capita income is more realistic than measuring it from changes in total income, since per capita income is not affected by changes in population. This assumption is illustrated with an operational example under Definition of Terms in chapter 1 .

\section{Cobb-Douglas Components}

The first three independent variables are derived from the Cobb-Douglas model: physical capital, labor, and technology (Cobb \& Douglas, 1928). The proxy for physical capital is the change in the value of the physical capital formation, regardless of its domestic or foreign ownership. To avoid the effect of wage differentials in the total cost of the workforce, the proxy of labor was determined to be the change in the number of members of the workforce.

Technology in the Cobb-Douglas model is predetermined, and it is represented by a constant term (a) and the constant exponents of capital $(\alpha)$ and labor $(\beta)$. For Cobb and Douglas (1928), the constant term was a condition of production independent from input, and the constant exponents were the output elasticity measures of the responsiveness of output to a change in levels of either labor or capital used in production. Technology in their model, therefore, was a particular combination of capital and labor under certain 
production conditions. For the purpose of this study, technology is supposed to be affected by other factors in the model, such as higher education and globalization. These constant components, therefore, were replaced with a variable consistent with the concept of technology in the Cobb-Douglas model - the proportion of capital to labor.

In theory, technology in the Cobb-Douglas model is any combination of capital and labor that does not necessarily rank technology at any particular level. In this study, however, technology is assumed to be ranked at high or low levels by the proportion of capital to labor. Based on this assumption, the production process is seen as a spectrum of technology, where labor intensive process (more use of labor than physical capital) would be in one extreme of the continuum and capital intensive (more use of physical capital than labor) in the other. To the extent that the level of technology increases, the production process would move away from labor intensive and closer to capital intensive. This means that the more physical capital is used in the production process the higher the level of technology would be. For that assumed reason, the proxy for technology was determined to be the change in the proportion of physical capital to labor.

Other measures of technology were considered in the search for the most suitable variable of technology to be included in this model, as it was the case of patent statistics. It is widely accepted that patent statistics are a reliable (although not perfect) indicator of innovative activity. Therefore, it has become standard practice to use patent statistics for monitoring innovative activities and the development of new technologies (World Intellectual Property Organization., 2008). Some reasons, however, prevented the use of this measure. One was that not all inventions are patented. There are other alternatives such as trade secrecy or technical know-how available to inventors for protecting their 
inventions. Another reason was that due to the increase in the internationalization of research and development (R\&D) activity, R\&D may be conducted in one location but the protection for the invention might be sought in a different one. Finally, the most reliable source of patent statistics is the World Patent Report compiled by the World Intellectual Property Organization (WIPO), which has been published only for the last three years.

\section{The Solow Model Component}

The next variable is derived from the Solow model: productivity of investment (Solow, 1956). The productivity measured in the Solow model refers to returns of physical capital. It measures the amount of physical capital necessary to produce a unit of output. According to Solow (1956), the lower the proportion of physical capital to output, the higher the productivity of investment will be. Increase in productivity of investment, therefore, means that less necessary capital is needed to produce the same amount of output. The most common way to measure productivity, however, is to calculate production productivity - the amount of output obtained from a unit of input. The higher the output per unit of input, the higher the product productivity will be (Gaither \& Gray, 1996). It means that there is a direct relationship between output and productivity. As this is the method that better fits this model, Solow's productivity of investment was changed to production productivity in this study.

\section{Education Components}

This study analyzes the contribution of higher education to economic development, but higher education is not independent from the other levels. Formal education is sequential and each level depends on the previous one. No student graduates 
from college without first completing the primary and secondary levels. Therefore, the results of this model would not be accurate if the change in economic growth that is explained by each level of education is not identified. In the interaction term $\left(\Delta h e^{*} \Delta f d i\right)$ of the last equation, however, only higher education is included. The reason for this is because the main purpose of this study is to analyze the contribution of only higher education to economic development when it interacts with globalization. The primary and secondary levels of education measured the variance of economic growth explained by formal education that is not explained by higher education. The comparisons of these variances, however, made evident the importance of the contribution of secondary education to economic growth in less developed countries.

Education, therefore, was split into three variables: primary, secondary, and higher education. Then they were lagged to make their effect fit the timeframe of the period used for this study. These variables measure the change in completion at each corresponding level of formal education. The reason to choose completion was to keep consistency between the measuring basis of the variables of education (number of graduates) and labor (number of members of the workforce).

\section{Education Lagging Procedure}

What makes the education variable more complex is that its effect is not immediate-it changes the nature of society some years after the education of the individual. The three resulting variables are lagged based on the readiness of graduates to become active and productive members of the workforce working at their full potential. Many factors influence the length of time that a graduate needs to get ready for work, such as job search, entry level position orientation and training, and enrollment in the 
following education level. Therefore, the following lag periods were established for each variable. The lag for primary completion was 15 years. This is the longest lag because of the time that graduates at this level need to reach the legal working age or to complete the following level. For secondary, the lag was 10 years. This lag is determined by the time that would take a graduate to find a job and get trained to compensate for experience and college studies or eventually seek a college degree. Finally, higher education was lagged 5 years. The main reason for the lags of this level is the possibility of staying longer out of the workforce to seek higher degrees.

\section{Economic Development Component}

The variable of economic development measures the change in the HDI, which is based on the UNDP's concept of human development (Human Development Reports UNDP, n.d.). The HDI is a summary composite index that measures a country's average achievements in three basic aspects of human development: health, knowledge, and a decent standard of living. Health is measured by life expectancy at birth; knowledge is measured by a combination of the adult literacy rate and the combined primary, secondary, and tertiary gross enrollment ratio; and standard of living as measured by GDP per capita (Human Development Reports -UNDP, n.d.). The index is a fraction ranging between the virtually impossible extreme values 0 and 1 , where 0 equals no human development at all and 1 equals perfect human development. This is a comprehensive index that includes necessary conditions for economic development to occur. 


\section{The Globalization Component}

The last variable of the model measures, according to the proportion of FDI to GDP, how much the economies under study are exposed to a globalized environment,. This variable measures the change in the UNCTAD Inward FDI Performance Index (UNCTAD.ORG FDI Indices, n.d.). This index ranks countries by the FDI they receive relative to their economic size. It is the ratio of a country's share in global FDI inflows to its share in global GDP. A value greater than 1 indicates that the country receives more FDI than its relative economic size, whereas a value below 1 means that it receives less (a negative value means that foreign investors disinvest in that period). The index thus captures the influence on FDI of factors other than market size, assuming that, other things being equal, size is the "base line" for attracting investment. These other factors can be diverse, ranging from the business climate, economic and political stability, and the presence of natural resources, infrastructure, skills and technologies to opportunities for participating in privatization or the effectiveness of FDI promotion (UNCTAD.ORG Inward FDI Performance Index: Methodology, n.d.). The following formula is used by UNCTAD to calculate the Inward FDI Performance Index:

$$
I N D_{i}=\frac{F D I_{i} \div F D I_{w}}{G D P_{i} \div G D P_{w}}
$$

Where:

$\mathrm{IND}_{\mathrm{i}}=$ the inward FDI performance index of the $\mathrm{i}^{\text {th }}$ country

$\mathrm{FDI}_{\mathrm{i}}=$ the FDI inflows in the $\mathrm{i}^{\text {th }}$ country

$\mathrm{FDI}_{\mathrm{w}}=$ world $\mathrm{FDI}$ inflows 


$$
\begin{aligned}
& \mathrm{GDP}_{\mathrm{i}}=\text { GDP in the } \mathrm{i}^{\text {th }} \text { country } \\
& \mathrm{GDP}_{\mathrm{w}}=\text { World GDP }
\end{aligned}
$$

\section{Data Analysis Procedure}

The data was organized in three datasets. The main dataset includes the data of the 91 countries chosen for this study (see Appendix D). The two equations were run with this dataset to compare their $\mathrm{R}^{2}$ values, and the difference in $\mathrm{R}^{2} \mathrm{~s}$ estimated the amount of variance explained (or, added) by the interaction of higher education and globalization. The other two datasets were the result of splitting the main dataset into two groups of countries according to their level of economic development (see Appendixes $\mathrm{E}$ and F). The criteria used to split the main dataset into high and low levels of development was the 2007/2008 Human Development Index Rankings of the UNDP Human Development Report (Statistics - Human Development Reports [UNDP], n.d.). The purpose of these two datasets was to measure how much variance of economic growth was explained by the change in different levels of formal education in developed and less developed economies.

\section{Summary}

The literature that I reviewed for this study has contributed to my efforts in the development of this model. In this study, I address the issue of higher education by including higher education together with its previous levels (primary and secondary); as in Agiomirgianakis, Asteriou, and Monastiriotis, (2002) and Keller (2006); but measuring completion, as in Vedder (2004). These variables measure not only the contribution of higher education to economic growth, but also how different that contribution is from the contribution of the primary and secondary levels. The issue of globalization is addressed 
by including FDI in my model, as in Makki and Somwaru (2004), but not trade. One of the advantages of FDI over trade is that it not only measures the contribution of globalization to economic growth, but also the influence that the transfer of technology implicit in FDI may have on the level of technology of the economy.

The importance of my model and, therefore, the main contribution to the body of literature in the field of educational leadership and policy studies is that it also addresses the issue of economic development. There is no economic development without economic growth. My model, like most models analyzing economic issues, measures economic growth. By adding the variable of economic development, however, the analysis focuses not only on the contribution of higher education to economic growth, but to economic development as well. Furthermore, the results of this model that are presented in the next chapter suggest that secondary and higher education contribution to economic growth is very substantial in less developed countries. Consequently, if the level of economic growth in a globalized context in those countries is increased by promoting and expanding secondary and higher education, the social connotations associated with this expansion would be the basis of the infrastructure and environment that support economic development. 


\section{CHAPTER IV}

\section{FINDINGS}

The contribution of education to economic growth has been largely investigated, and empirical evidence supports the assumption that education contributes to economic growth. This study, however, focuses on a more specific and less explored area of educational leadership and policy, and its purpose is to answer the following research question: Does higher education contribute to economic development in the context of globalization?

I approach this chapter by first focusing on the interaction of higher education and globalization of production. For that purpose, a model including a criterion, and nine predictors was run, interacting two of the predictors, to examine the relationship between per capita income and that interaction (see Table 3 for variable definitions). Then, the model was run to observe the relationship, first between higher education and per capita income, and second between globalization and per capita income. Furthermore, two more regressions were run, one for developed economies and the other for less developed ones, to compare the relationship between higher education and per capita income at different levels of economic development. Finally, to assess the importance of the contribution of higher education to economic growth within the formal education system, the relationship between higher education and per capita income was compared with the relationship between the preceding two levels of education (primary and secondary) and per capita income. Table 4 displays the descriptive statistics of the variables included in this model - the criterion variable and the nine predictive variables-including the term of interaction between higher education and globalization. 
Table 3

Variable Definitions

Variable Definition

Criterion Variable

Per Capita Income Change

Economic growth. Proportion of gross

domestic product (GDP) to population

Predictive Variables

Capital change

Physical capital formation. New equipment of production added to the economy

Labor change

Number of people actually working as active member of the workforce

Technology change

Proportion of capital to labor. Value of new capital divided by the workforce

Productivity change

Proportion of output to labor. Value of GDP divided by the workforce

Primary education completion change

Number of students who completed the primary level of education

Secondary education completion change

Number of students who completed the secondary level of education

Higher education completion change

Number of students who completed the tertiary level of education

Economic development change

Human development index (HDI). A condition of economic development

Globalization change

Inward foreign direct investment (FDI) index. Inward FDI performance

Higher education/globalization interaction Product of the variables of higher education and globalization

Note. All the variables measure the change of its value between the beginning and the end of the period of study. The variables of primary, secondary and higher education are lagged 15,10 and 5 years respectively. 
Table 4

Descriptive Statistics of the Variables of the Model Run for All the Countries Selected for this Study

Standard

\begin{tabular}{lcrrrr}
\multicolumn{1}{c}{ Variables } & N & Minimum & Maximum & Mean & Deviation \\
\hline Per capita income change & 91 & -52.7 & 173.5 & 30.8 & 48.9 \\
Capital change & 91 & -62.5 & 494.5 & 62.0 & 84.2 \\
Labor change & 91 & -6.5 & 103.1 & 25.3 & 16.8 \\
Technology change & 91 & $-6,097.6$ & $6,272.6$ & 470.3 & $1,643.4$ \\
Productivity change & 91 & $-7,301.6$ & $23,145.9$ & $3,310.7$ & $5,846.4$ \\
Primary education completion change & 91 & -20.0 & 9.8 & -1.1 & 5.7 \\
Secondary education completion change & 91 & -22.9 & 20.2 & 1.8 & 5.2 \\
Higher education completion change & 91 & 0.0 & 7.7 & 2.1 & 1.7 \\
Economic development change & 91 & -0.1 & 0.1 & 0.0 & 0.0 \\
Globalization change & 91 & -9.9 & 5.3 & -0.1 & 1.9 \\
Higher education/globalization interaction & 91 & -22.7 & 23.7 & -0.1 & 5.0 \\
\hline
\end{tabular}

Note, Refer to Table 3 for variable definitions

Interaction of Higher Education and Globalization

Empirical evidence suggests that higher education contributes to economic growth, as can be seen in the work of researchers on this topic such as Denison (1961); Mowery and Rosenberg (1989); Benhabib and Spiegel (1992); and Mankiw, Romer, and Weil (1992). The purpose of this study is to confirm that evidence, but from two different perspectives. First, the intention is to find whether that contribution is more substantial in 
a globalized environment. The other objective is to find whether it can be assumed that higher education contributes, not only to economic growth but to economic development as well. This last perspective will be discussed later in this chapter.

The assumption that the contribution of education to economic growth is more substantial in a globalized environment could not be confirmed. The results of this study suggest that the relationship between higher education and economic well being of a country does not appear to be affected by how much that country is involved in global networks of manufacturing. Whereas, taken together, all the factors included here do a good job of explaining how economic growth occurs in countries throughout the world, the interplay of higher education with global production does not play much of a role. As shown in Table 5 the interaction of higher education and globalization term explains a relatively small portion $(2.6 \%)$ of changes in economic growth.

Table 5

Model Summary Displaying the Effect of Adding the Higher Education and Globalization Interaction Term $(N=91)$

\begin{tabular}{lcccc}
\hline & & & Adjusted R & Std. Error of \\
Model & R & R Square & Square & the Estimate \\
\hline With interaction term & .820 & .672 & .631 & 29.710068 \\
Without interaction term & .804 & .646 & .607 & 30.675227 \\
\hline Variance explained by interaction & .026 & & \\
\hline
\end{tabular}

Furthermore, the coefficient of the interaction term is significant but negative (see Table 6). That suggests that higher education and globalizations do not help economic growth just because they are present together in the economy. The independent 
Table 6

Effect of Higher Education and Globalization Interaction on the Predictions of Changes in Income $(N=91)$

Beta Coefficients

\begin{tabular}{lcc}
\multicolumn{1}{c}{ Variable } & Inter $^{\mathrm{a}}$ & No Inter $^{\mathrm{a}}$ \\
\hline Capital change & $0.419^{* * *}$ & $0.394^{* * *}$ \\
Labor change & -0.310 & -0.356 \\
Technology change & -0.005 & -0.005 \\
Productivity change & 0.002 & 0.002 \\
Primary education completion change & -0.204 & -0.093 \\
Secondary education completion change & $1.575^{*}$ & $1.355^{*}$ \\
Higher education completion change & $5.699^{* *}$ & $5.430^{*}$ \\
Economic development change & 123.314 & 148.919 \\
Globalization change & $2.006^{*}$ & $-4.672^{*}$ \\
Higher education/globalization interaction & $-3.091^{*}$ & \\
\hline
\end{tabular}

Note. Regression with higher education and globalization interaction: $R=.820 ; R^{2}=.672$. Without interaction: $R=.804 ; R^{2}=.646$. Refer to Table 3 for variable definition $\mathrm{s}$

${ }^{a}$ Including the higher education and globalization in teraction term. ${ }^{b}$ Excluding the education and globalization interaction term

${ }^{*} p<.05 .{ }^{* *} p<.01 .{ }^{* * *} p<.001$

relationships of economic growth with higher education on the one hand and with globalization on the other hand, however, are assumed to be substantial. When the model is run with the interaction term (see Table X), the coefficient of higher education increases about 5\% (from 5.430 to 5.699) and improves its statistical significance (from $p$ $<.05$ to $p<.01$ ). With respect to globalization, its coefficient remains statistically 
significant and becomes positive (from -4.672 to 2.006 ). That suggests that, independently, higher education and globalization do contribute to economic growth. This conclusion is consistent with Katz's (2006) arguments about interaction terms. According to Katz, "if the impact of the two variables together is substantially less than the additive effect of the two variables, the coefficient will be negative and statistically significant." Figure 1 shows a graphical dimension of the coefficients of the higher education and globalization variables and their interaction in agreement with Katz's interaction concept.

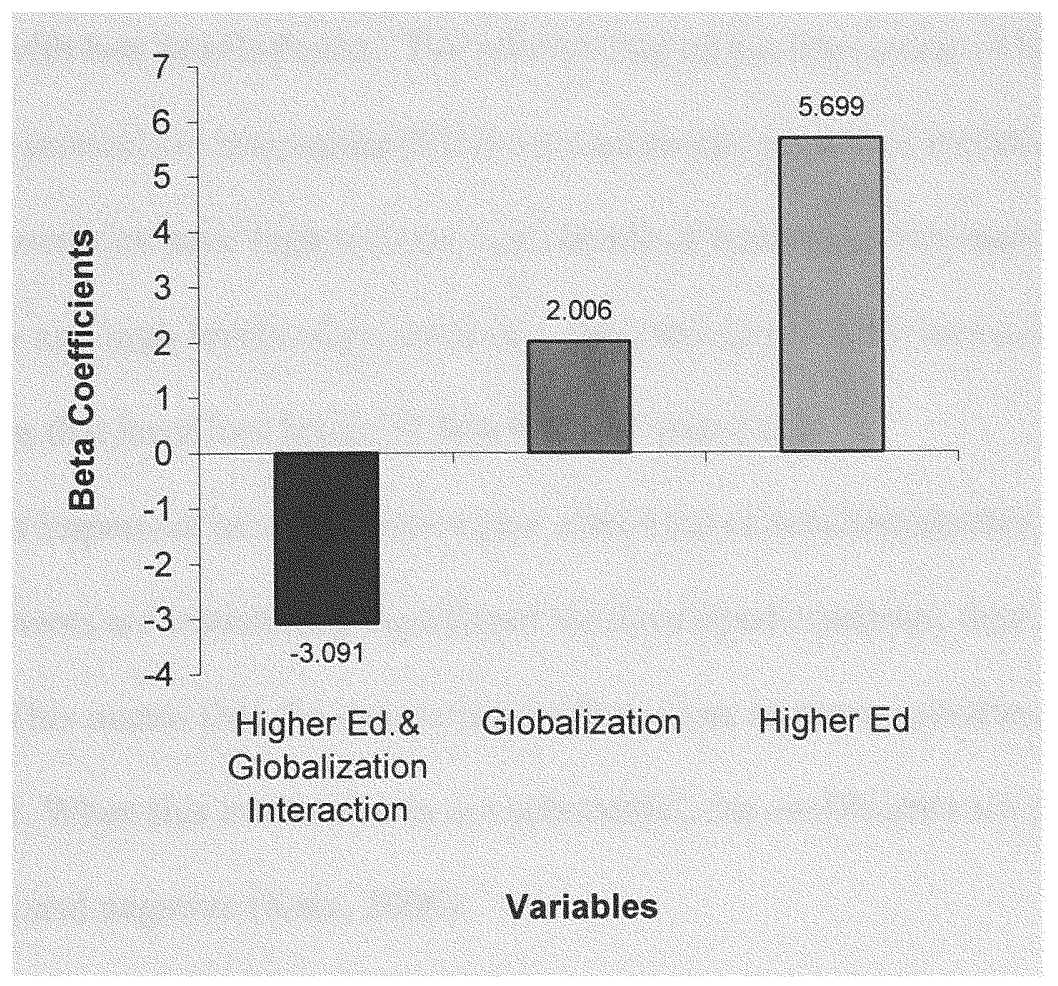

Figure 1. Comparison of the coefficients of higher education $(p=.01)$ and globalization $(p=.05)$ variables and their interaction $(p=.05)$.

The story is much more complex, though, than it appears at first. It makes sense that the relationship between higher education and economic growth would be enhanced 
when production in the country begins to link to a globalized system of production. After all, in order to bring in global manufacturing at least a minimal level of well educated people need to be engaged - if for no other reason than to provide infrastructural support in banking, communications, transportation and legal systems. In order to explore this, I ran the model again, this time separating countries with high development indicators from those with low development indicators. Table 7 displays the results.

A clear pattern emerges here. The interaction of higher education and production integration (FDI) does appear to matter in countries with high development but not for countries with low development. The relationship of the interaction of higher education and global production integration (FDI) with economic growth is statistically significant for when countries have high income, high levels of human development, high levels of technology and high levels of productivity. But, this interaction does not appear to matter in countries that have low levels of development (see Table 7).

It is important here to mention just what kind of relationship this is. Even though the coefficients are statistically significant for developed countries, they are negative (see Table 7). This means that the interaction matters more in those countries, but it is still not substantial. When this interaction is not substantial, the coefficients are generally significant and negative (Katz, 2006).

\section{Higher Education and Economic Growth}

The assumption that the contribution of higher education to economic growth was more substantial in a globalized environment could not be supported. This study, however, adds more empirical evidence to support the assumption that higher education, regardless of the degree of globalization of the economy, does contribute to economic 
growth. In order to analyze the relationship between higher education and per capita income, the results of the model were compared with the results of the same model, but run without the higher education term. As shown in Table 8, higher education accounts for about $2.7 \%$ of the change in per capita income.

Table 7

Interaction of Higher Education and Foreign Direct Investment on Countries Grouped by High and Low Development Indicators $(N=91)$

Beta

Indicator and level Coefficient

Income

High income countries $-4.5^{*}$

Low income countries

Technology

High technology level countries $-4.5^{*}$

Low technology level countries

Productivity

High levels of productivity countries $-4.5^{*}$

Low levels of productivity countries

Human development index score (development)

High HDI countries

Low HDI countries

Foreign direct investment (globalization)

High FDI inflow countries

Low FDI inflow countries

$-1.6$

Note. Chance of this effect occurring randomly is less than $5 \%$

${ }^{*} p<.05$. 
Table 8

Model Summary Displaying the Effect of Adding the Higher Education Term $(N=91)$

\begin{tabular}{lcccc}
\hline Model & R & R Square & Square & $\begin{array}{c}\text { Std. Error of } \\
\text { the Estimate }\end{array}$ \\
\hline With Higher Ed term & .804 & .646 & .607 & 30.675227 \\
Without Higher Ed term & .787 & .619 & .582 & 31.642823 \\
\hline Variance explained by higher education & .027 & & \\
\hline
\end{tabular}

The coefficients of the two regressions were also compared. As shown in Table 9, the coefficient of higher education is positive and statistically significant, which supports the assumption that higher education contributes to economic growth. Another important aspect of this analysis is that, after adding the higher education term, the secondary education coefficient increased about $17 \%$ (from 1.160 to 1.355 ) and became statistically significant. This was the first indication in this study that the relationship of economic growth with secondary education could be as substantial as its relationship with higher education. I share this assumption with Keller (2006) who argued that countries grow faster by raising enrollment rates in secondary and higher education. Finally, as displayed in Table 9, even though the coefficient of economic development, before and after adding the higher economic term, is not statistically significant, it increased about $19 \%$ (from 125.139 to 148.919$)$. This was another sign suggesting that higher education could contribute not only to economic growth, but to economic development as well. To this respect, Teferra and Altbach (2004) have stated that higher education is recognized as a key force for modernization and development. 
Table 9

Effect of Higher Education on the Predictions of Changes in Income $(N=91)$

\begin{tabular}{lcc}
\hline & \multicolumn{2}{c}{ Beta Coefficients } \\
& $\mathrm{HE}^{\mathrm{a}}$ & $\mathrm{No} \mathrm{HE}^{\mathrm{a}}$ \\
\hline Capital change & $0.394 * * *$ & $0.411^{* * *}$ \\
Labor change & -0.356 & -0.269 \\
Technology change & -0.005 & -0.006 \\
Productivity change & 0.002 & $0.003^{* *}$ \\
Primary education completion change & -0.093 & -0.438 \\
Secondary education completion change & $1.355^{*}$ & 1.160 \\
Higher education completion change & $5.430^{*}$ & \\
Economic development change & 148.919 & 125.139 \\
Globalization change & $-4.672^{*}$ & $-4.702^{*}$ \\
\hline
\end{tabular}

Note. Regression with higher education: $R=.804 ; R^{2}=.646$. Without higher education: $R=.787 ; R^{2}=.619$.

Refer to Table 3 for variable definitions

${ }^{a}$ Including higher education. ${ }^{b}$ Ex cluding higher education

${ }^{*} p<.05 .{ }^{* *} p<.01 .{ }^{* * *} p<.001$

\section{Globalization and Economic Growth}

. The same procedure followed to analyze the relationship between higher education and per capita income was followed to analyze the relationship between globalization and per capita income. This time, the results of the model were compared with the results of the same model, but now without the globalization term. The results happened to be very similar to the results of the higher education analysis. Globalization explains also about $2.7 \%$ of the per capita income variance (see Table 10 ). 
Table 10

Model Summary Displaying the Effect of Adding the Globalization Term $(N=91)$

\begin{tabular}{lcccc}
\hline Model & R & R Square & Square & $\begin{array}{c}\text { Adjusted R } \\
\text { the Estimate }\end{array}$ \\
\hline With Global term & .804 & .646 & .607 & 30.675227 \\
Without Global term & .787 & .619 & .582 & 31.630628 \\
\hline Variance explained by globalization & .027 & & \\
\hline
\end{tabular}

In this case, in spite of the fact that the relationship of the interaction of higher education and globalization with economic growth is not substantial, the relationship between globalization and per capita income is positive and statistically significant. The results of these analyses of the relationship with economic growth of the interaction of higher education and globalization first, and separately with higher education and globalization afterward, are consistent with Katz's (2006) arguments - the relationship of economic growth with the interaction of higher education and globalization is less substantial than its separate relationship with higher education and globalization.

As in the case of the higher education analysis, the coefficients of the two regressions were also compared (see Table 11). The coefficient of globalization is statistically significant but negative. That suggests that globalization does not help the selected countries accelerate economic growth in a direct way, although it could help them indirectly. By adding the globalization term, the higher education coefficient remains almost unchanged. The coefficients of economic development, however, decreased about $20 \%$ (from 185.766 to 148.919 ). That suggest that globalization does not 
Table 11

Effect of Globalization on the Predictions of Changes in Income $(N=91)$

Beta Coefficients

\begin{tabular}{lll} 
Variable & Glob $^{\mathrm{a}} \quad$ No Glob \\
\hline
\end{tabular}

Capital change

$\begin{array}{ll}0.394 * * * & 0.360 * * * \\ -0.356 & -0.375 \\ -0.005 & -0.003 \\ 0.002 & 0.002\end{array}$

Primary education completion change

$-0.093$

0.239

Secondary education completion change

$1.355^{*}$

1.221

Higher education completion change

$5.430 *$

$5.464^{*}$

Economic development change

148.919

185.766

Globalization change

$-4.672 *$

Note. Regression with globalization: $R=.804 ; R^{2}=.646$. Without globalization: $R=.787 ; R^{2}=.619$

Refer to Table 3 for variable definitions

${ }^{a}$ Including globalization. ${ }^{b}$ Exclu ding globalization

${ }^{*} p<.05 .{ }^{* * *} p<.001$

help those countries with their economic development either. Globalization, however, could indirectly help the economy. As shown in Table 10, the coefficient of globalization increased about $11 \%$ (from 1.221 to 1.355 ) and became statistically significant. That suggests that secondary education could help the selected countries, even more than higher education, in a globalized environment. Attention is been paid in England and the United States to secondary education because of the influence of globalization and its emphasis on schooling as an adjunct to economic success (Holt, 2001). 
Higher Education and Economic Development

This study emphasizes not only the relationship between higher education and economic growth, but also the relationship between higher education and economic development. In order to measure the variance of per capita income due to changes in higher education in an economic development context, the 91 countries selected for this study were split into two groups. The criteria used to form the two groups of countries was the development classification created by the United Nations Development Programme (UNDP), an organization that ranks countries according to their level of development (Statistics - Human Development Reports [UNDP], n.d.).. One group included 41 countries which were those within the UNDP classification of countries ranging from top middle to high level of development (see Appendix E). The other group included the remaining 50 countries that were those within the UNDP classification of countries ranging from bottom middle to low level of development (see Appendix F). Higher Education in Top Mid to Highly Developed Economies

To analyze the relationship between higher education and per capita income within the context of economic development, the model was run first for the group of countries ranging from the top mid to highly level of development. The model was run twice for this group. First, it was run including the nine predictors. Then it was run without the higher education variable. According to the results of both regressions, higher education accounts for only half of $1 \%$ of the change in per capita income (see Table 12). As this study is about change, it is just change in higher education completion which is not substantial in the relationship between higher education and economic growth. 
Table 12

Model Summary Displaying the Effect of Adding the Higher Education Term in Top Mid to Highly Developed Economies $(N=41)$

\begin{tabular}{lcccc}
\hline Model & $\mathrm{R}$ & R Square & $\begin{array}{c}\text { Adjusted R } \\
\text { Square }\end{array}$ & $\begin{array}{c}\text { Std. Error of } \\
\text { the Estimate }\end{array}$ \\
\hline With Higher Ed term & .758 & .575 & .452 & 28.416174 \\
Without Higher Ed term & .755 & .570 & .462 & 28.136813 \\
\hline Variance explained by higher education & .005 & & \\
\hline
\end{tabular}

Further findings can be drawn by comparing the coefficients of the two regressions. According to Table 13, the coefficient of the higher education variable is negative for the first time in this study, and the rest of the coefficient experienced no substantial change. The most remarkable result of these regressions, however, is that, except for the coefficient of the physical capital variable, all other coefficients are not statistically significant. Developed countries are assumed to have stable economies that are mainly concerned about keeping steady rates of economic growth. For these countries, changing the status quo of the economy is not an issue. As this study is about change, the analyses of changes in variables that lead the countries' efforts more toward economic development than toward economic growth, such as education, should not be expected to generate significant results. If that is that is the case, the findings obtained from the regressions of the model run for the less developed economies are supposed to be more significant. 
Table 13

Effect of Higher Education on the Predictions of Changes in Income in Top Mid to Highly Developed Economies $(N=41)$

Beta Coefficients

\begin{tabular}{|c|c|c|}
\hline Variable & $\mathrm{HE}^{\mathrm{a}}$ & No $\mathrm{HE}^{\mathrm{a}}$ \\
\hline Capital change & $0.268 * * *$ & $0.264 * * *$ \\
\hline Labor change & -0.193 & -0.187 \\
\hline Technology change & -0.001 & -0.001 \\
\hline Productivity change & 0.002 & 0.002 \\
\hline Primary education completion change & -0.320 & -0.221 \\
\hline Secondary education completion change & 0.599 & 0.701 \\
\hline Higher education completion change & -1.907 & \\
\hline Economic development change & 348.268 & 295.928 \\
\hline Globalization Change & -2.757 & -2.841 \\
\hline
\end{tabular}

Note. Regression with higher education: $R=.758 ; R^{2}=.575$. Without higher education: $R=.755 ; R^{2}=.570$.

Refer to Table 3 for variable definitions

${ }^{a}$ Including higher education. ${ }^{b}$ Excluding higher education

${ }^{* * *} p<.001$

Higher Education in Bottom Mid to Less Developed Economies

To continue the analysis of the relationship between higher education and per capita income within the context of economic development, the model was also run twice for the group of bottom mid to less developed economies. It was run first including the nine predictors, and then it was run without the term of higher education. After comparing the results of both regressions, it was found that higher education accounts for 
approximately $6.6 \%$ of the variance of per capita income in less developed economies (see Table 14).. In contrast with the results of previous group, the results of this group promise to be more interesting.

Table 14

Model Summary Displaying the Effect of Adding the Higher Education Term in Bottom Mid to Less Developed Economies $(N=50)$

Adjusted R Std. Error of

\begin{tabular}{lcccc} 
Model & R & R Square & Square & the Estimate \\
\hline With Higher Ed term & .924 & .854 & .821 & 23.108665 \\
Without Higher Ed term & .888 & .788 & .747 & 27.489811 \\
\hline
\end{tabular}

Variance explained by higher education $\quad .066$

In order to confirm the validity of this previous result for this group of countries, the coefficients of the two regressions were also compared. As displayed in Table 15, the coefficient of higher education in statistically significant $(p<.001)$. The coefficient of the secondary education variables remains almost unchanged and statistically significant $(p<$ .001). Furthermore, even though the coefficient of economic development is not statistically significant, it jumped from 3.718 to 65.792 when the variable of higher education was added. These findings support the assumption that less developed economies are more sensitive to the change of variables that steer the countries' efforts, not only toward the attainment of economic growth, but also toward the achievement of higher levels of economic development.

This study contrasts with that of Folson (2006). She considers the revival of higher education as crucial to national development in the era of globalization. Folson, 
Table 15

Effect of Higher Education on the Predictions of Changes in Income in Bottom Mid to Less Developed Economies $(N=50)$

Beta Coefficients

\begin{tabular}{|c|c|c|}
\hline Variable & $\mathrm{HE}^{\mathrm{a}}$ & No $\mathrm{HE}^{\mathrm{a}}$ \\
\hline Capital change & $0.358 * * *$ & $0.398 * * *$ \\
\hline Labor change & $-0.515^{*}$ & -0.157 \\
\hline Technology change & 0.004 & -0.017 \\
\hline Productivity change & $0.012 *$ & $0.019 * *$ \\
\hline Primary education completion change & $-3.403^{*}$ & $-3.533^{*}$ \\
\hline Secondary education completion change & $9.543 * * *$ & $9.848 * * *$ \\
\hline Higher education completion change & $10.574 * * *$ & \\
\hline Economic development change & 65.792 & 3.718 \\
\hline Globalization Change & $-5.327^{*}$ & -5.971 \\
\hline
\end{tabular}

Note. Regression with higher education: $R=.924 ; R^{2}=.854$. Without higher education: $R=.888 ; R^{2}=.788$

Refer to Table 3 for variable definitions

${ }^{a}$ Including higher education. ${ }^{b}$ Excluding higher education

${ }^{*} p<.05 .{ }^{* *} p<.01,{ }^{* * *} p<.001$

however, also argues that While higher education output in advanced scientific and technical occupations may lead to development in some specific contexts, this output could, in other contexts, be substantially in excess of existing acceptable career opportunities, causing significant brain drain.

In a similar work to this study, however, Egger, Egger, Falkinger, and Grossmann (2005) examined the relationship of higher education and economic growth in a 
globalized environment. They used a database of 87 countries, of which 80 are included in this study, and analyzed the period from 1960 to 2000, which also includes the time period of this study. Using foreign direct investment (FDI) as a measure for globalization, Egger et al. presented empirical evidence which largely supported the assumption that increased participation in higher education enhances productivity progress and thereby fosters economic growth.

Nevertheless, these results suggest that this model is more suitable for the analysis of the relationship between higher education and economic growth in less developed countries. This model has been run with three different sets of data and the results show that it is relative strong for the three regressions. This model, however, seems to be stronger when run for less developed economies. Figure 2 graphically compares the strength of the model for each regression.

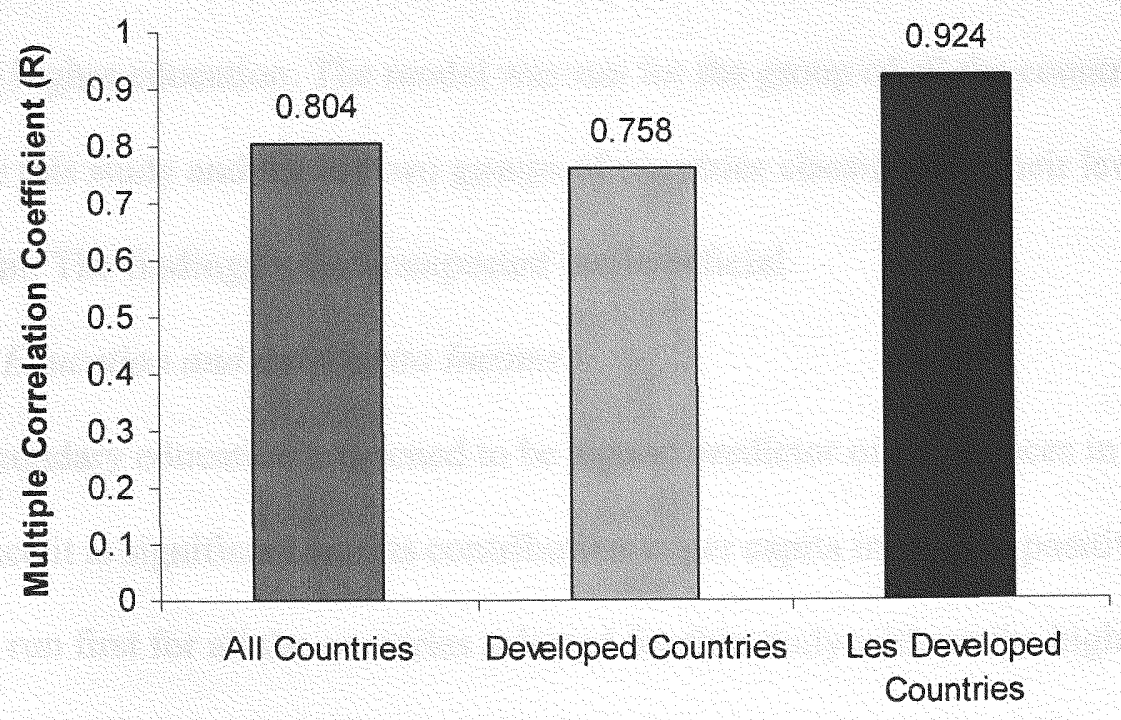

Countries

Figure 2. Model statistical strength measured by the multiple correlation coefficient (R). 
Even though this study emphasizes higher education, the education levels preceding it (primary and secondary) are also included in the model. The contribution of the primary education level to the variance of per capita income does not appear to be substantial. Its contribution is negative and not significant. The lack of relevance of primary education in the production process could have two main causes. On the one hand, workforce members with a primary education level do not contribute much to the levels of human capital, technology, and productivity in the economy. On the other hand, because of the age of students graduating from primary education, they usually hit the workforce with a higher level of education.

The secondary education level, however, seems to be relevant. Its contribution is positive and significant. For that reason, the relationship between economic growth and secondary education was analyzed the same way as the relationship between economic growth and higher education. The model was run for the group of all the countries selected for this study and for the two groups of countries classified by their level of development. The findings were unexpected but beneficial. Secondary Education and per Capita Income

Secondary education happened to be a good predictor of differences in economic growth, since it is significant and its contribution to per capita income is positive. The model was run first for all the countries selected for this study without the higher education term. The results of this regression were compared with the results of the same model with the nine predictors, which are presented in Table 16 and Table 17. 
Table 16

Model Summary Displaying the Effect of Adding the Secondary Education Term $(N=91)$

\begin{tabular}{lcccc}
\hline & & & Adjusted R & Std. Error of \\
Model & $\mathrm{R}$ & R Square & Square & the Estimate \\
\hline With Secondary Ed term & .804 & .646 & .607 & 30.675227 \\
Without Secondary Ed term & .792 & .626 & .590 & 31.318918 \\
\hline Variance explained by secondary education & .020 & & \\
\hline
\end{tabular}

Table 17

Effect of Secondary Education on the Predictions of Changes in Income $(N=91)$

Beta Coefficients

\begin{tabular}{|c|c|c|}
\hline Variable & $\mathrm{SE}^{\mathrm{a}}$ & No $\mathrm{SE}^{\mathrm{a}}$ \\
\hline Capital change & $0.394 * * *$ & $0.398 * * *$ \\
\hline Labor change & -0.356 & -0.369 \\
\hline Technology change & -0.005 & -0.005 \\
\hline Productivity change & 0.002 & $0.002 *$ \\
\hline Primary education completion change & -0.093 & 0.132 \\
\hline Secondary education completion change & $1.355^{*}$ & \\
\hline Higher education completion change & $5.430^{*}$ & $4.872^{*}$ \\
\hline Economic development change & 148.919 & 164.475 \\
\hline Globalization change & $-4.672 *$ & $-4.339^{*}$ \\
\hline
\end{tabular}

Note. Regression with Secondary education: $R=.804 ; R^{2}=.646$. Without Secondary education: $R=.792$;

$R^{2}=.626$. Refer to $\mathrm{T}$ able 3 for variable definitions

${ }^{a}$ Including secondary education. ${ }^{b}$ Excluding second ary education

${ }^{*} p<.05 .{ }^{* * *} p<.001$ 
This analysis suggests that secondary education accounts for about $2 \%$ of the per capita income variance. After adding the secondary education term, two remarkable results can be seen. First, the coefficient of secondary education is positive and statistically significant. Second, the coefficient of higher education increased about $11 \%$ and remained statistically significant. The relationship of economic growth with higher education, however, seems to be more substantial than with secondary education for all the countries selected for this study, as can be seen in Figure 3.

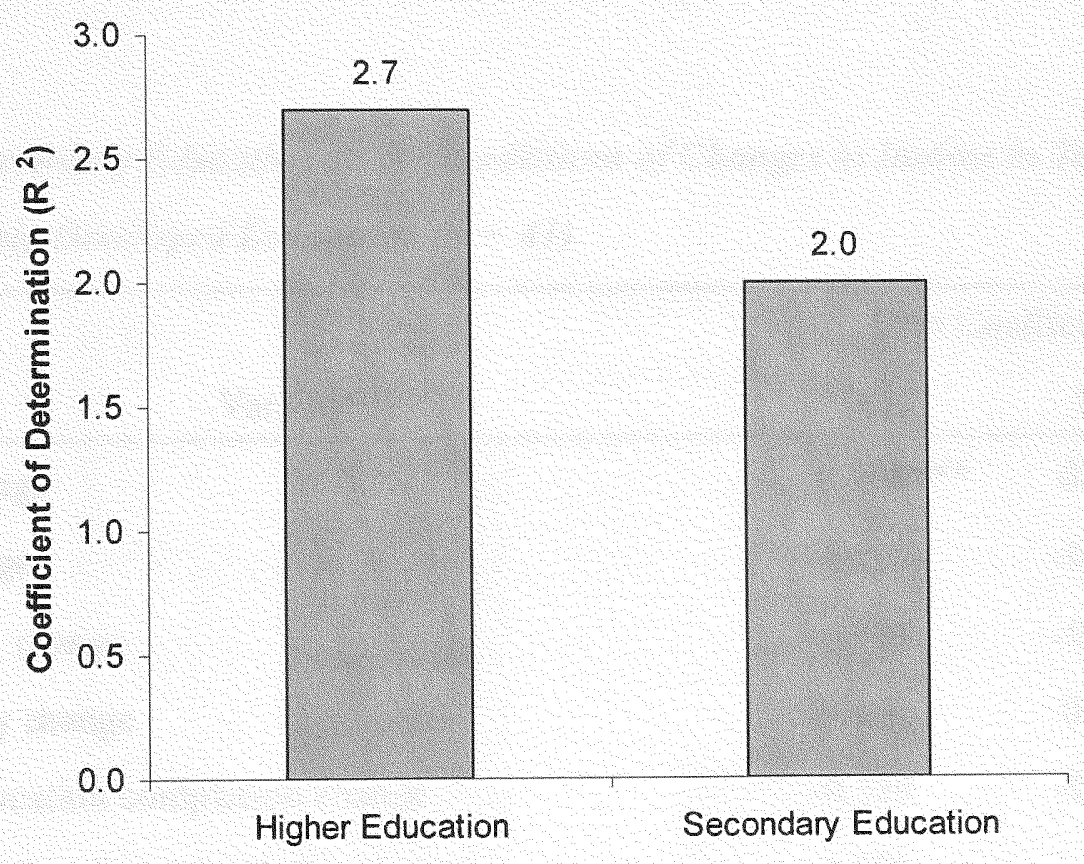

Variables

Figure 3. Comparison of the per capita income variance explained by changes in the completion of higher education and secondary education in all countries. Secondary Education in Top Mid to Highly Developed Economies

Two regressions were run for the top mid to highly developed countries with and without the secondary education term. The results are shown in Table 18 and Table 19. 
Table 18

Model Summary Displaying the Effect of Adding the Secondary Education Term in Top Mid to Highly Developed Economies $(N=41)$

\begin{tabular}{lcccc}
\hline Model & R & R Square & $\begin{array}{c}\text { Adjusted R } \\
\text { Square }\end{array}$ & $\begin{array}{c}\text { Std. Error of } \\
\text { the Estimate }\end{array}$ \\
\hline With Secondary Ed term & .758 & .575 & .452 & 28.416174 \\
Without Secondary Ed term & .751 & .563 & .454 & 28.352207 \\
\hline Variance explained by secondary education & .012 & & \\
\hline
\end{tabular}

Table 19

Effect of Secondary Education on the Predictions of Changes in Income in Top Mid to Highly Developed Economies $(N=41)$

Beta Coefficients

\begin{tabular}{|c|c|c|}
\hline Variable & $\mathrm{SE}^{\mathrm{a}}$ & No $\mathrm{SE}^{\mathrm{a}}$ \\
\hline Capital change & $0.268 * * *$ & $0.272 * * *$ \\
\hline Labor change & -0.193 & -0.220 \\
\hline Technology change & -0.001 & -0.001 \\
\hline Productivity change & 0.002 & 0.002 \\
\hline Primary education completion change & -0.320 & -0.216 \\
\hline Secondary education completion change & 0.599 & \\
\hline Higher education completion change & -1.907 & -2.652 \\
\hline Economic development change & 348.268 & 409.652 \\
\hline Globalization Change & -2.757 & -2.533 \\
\hline
\end{tabular}

Note. Regression with Secondary education: $R=.758 ; R^{2}=.575$. Without Secondary education: $R=.751$;

$R^{2}=.563$. Refer to Table 3 for variable definitions

${ }^{a}$ Including secondary education. ${ }^{b}$ Excluding second ary education

$* * * p<.001$ 
It is surprising how higher education and secondary education switch their roles when the analysis is focused on this group of developed economies. The results show that about $1.2 \%$ of the variance of per capita income is explained by secondary education. This is more than double the half of $1 \%$ explained by higher education for the same group of countries. Even though the role of secondary education in these economies is not statistical significant (see Table 19), it is still more substantial than the role of higher education. Figure 4 shows graphically how different the roles of the two levels of education are when the analysis focuses on developed countries.

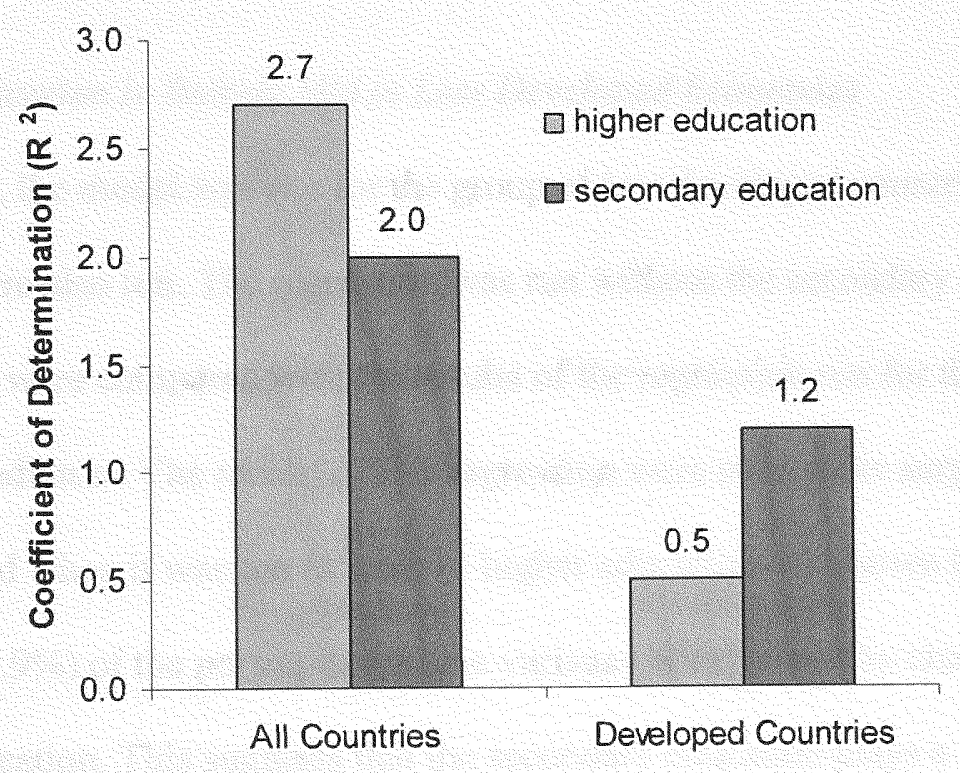

Variables

Figure 4. Comparison of the per capita income variance explained by changes in the completion of higher education and secondary education in all countries with the variance explained in developed countries. 
According to Holt (2001), the pressure for student performance, the quest for absolute standards, and the premium placed on information technology have made secondary education the center of attention in the United States and the United Kingdom. Those, therefore, may also be some of the reasons why the secondary education plays a substantial role in developed economies.

The results of these regressions, however, are still far from suggesting that changes in secondary education completion, as it is the case of higher education, substantially contribute to economic growth. As displayed in Table 19, even though the coefficient of the secondary education variable is positive, it is not statistically significant.

Secondary Education in Bottom Mid to Less Developed Economies

Finally, the model was run for the group of less developed countries. Two regressions were also run. The regression was run without the secondary education term, and the results were compared with the results of the regression run for the same group with all the predictors. The results of this regression were even more surprising than the results obtained when it was run to analyze higher education. As shown in Table 20, almost $10 \%(9.9 \%)$ of the per capita income variance is explained by changes in secondary education. This suggests that the secondary education plays a substantial role in the economy of this group of countries. The reason for that could be that many less developed countries keep low levels of technology, and most of the demand for qualified workforce can be met by secondary education graduates. More interesting findings can be seen in Table 21 where the coefficients of the two regressions are compared. 
Table 20

Model Summary Displaying the Effect of Adding the Secondary Education Term in Bottom Mid to Less Developed Economies $(N=50)$

\begin{tabular}{lcccc}
\hline Dataset & R & R Square & $\begin{array}{c}\text { Adjusted R } \\
\text { Square }\end{array}$ & $\begin{array}{c}\text { Std. Error of } \\
\text { the Estimate }\end{array}$ \\
\hline With Secondary Ed term & .924 & .854 & .821 & 23.108665 \\
Without Secondary Ed term & .869 & .755 & .708 & 27.489811 \\
\hline Variance explained by secondary education & .099 & & \\
\hline
\end{tabular}

Table 21

Effect of Secondary Education on the Predictions of Changes in Income in Bottom Mid to Less Developed Economies $(N=50)$

Beta Coefficients

\begin{tabular}{|c|c|c|}
\hline Variable & $\mathrm{SE}^{\mathrm{a}}$ & No $\mathrm{SE}^{\mathrm{a}}$ \\
\hline Capital change & $0.358 * * *$ & $0.427 * * *$ \\
\hline Labor change & $-0.515^{*}$ & -0.535 \\
\hline Technology change & 0.004 & -0.001 \\
\hline Productivity change & $0.012 *$ & 0.006 \\
\hline Primary education completion change & $-3.403 *$ & -1.424 \\
\hline Secondary education completion change & $9.543 * * *$ & \\
\hline Higher education completion change & $10.574 * * *$ & $11.079 * *$ \\
\hline Economic development change & 65.792 & 128.202 \\
\hline Globalization Change & $-5.327^{*}$ & -5.433 \\
\hline
\end{tabular}

Note. Regression with Secondary education: $R=924 ; R^{2}=.854$. Without Secondary education: $R=.869$;

$R^{2}=.755$. Refer to Table 3 for variable definitions

${ }^{a}$ Including secondary education. ${ }^{b}$ Excluding secondary education

$*_{p}<.05 . *{ }^{*} p<.01 . * * *_{p}<.001$ 
There are three main findings resulting from comparing the coefficients, which are worth the attention. The first one is that the coefficient of the secondary education variable is positive and statistically significant $(p=.001)$. The second one is that, after adding the secondary education term, the coefficient of the higher education variable not only remained positive, but increased its statistical significance (from $p=.01$ to $p=.001$ ) as well. Finally, the coefficient of the primary education variable, even though it remains negative, it became statistically significant $(p=.05)$ for the first time in this study.

It is also interesting the fact that the contribution of higher education to economic growth in les developed countries is also substantial, since it explains about $6.6 \%$ of the variance of per capita income (see Table 14). Both higher and secondary education, therefore, explain about $16.5 \%$ of the variance of per capita income in those economies (see Figure 5).

These results support the assumption that the relationship between changes in economic growth and changes in education, mainly in higher and secondary levels, may be substantial and positive in the economy of less developed countries. Figure 5 shows the role of those two levels of education in developed and less developed economies compared with their role in all the countries selected for this study.

The development of adequate secondary education programs, mainly in less developed countries, has been the concern of scholars in the educational leadership and policy area in recent years. Quist (2003) argued that all the models of secondary education transferred and adapted since colonial times have greatly contributed to Ghana's human-resource and socio-political development. Quist added that without the implementation of these models the country could not have produced in the past forty 
years its critical human-resource base crucial not only to Ghana's early attainment of self-rule and political independence from Britain, but also its continued attempts at systematic and sustained socio-political development.

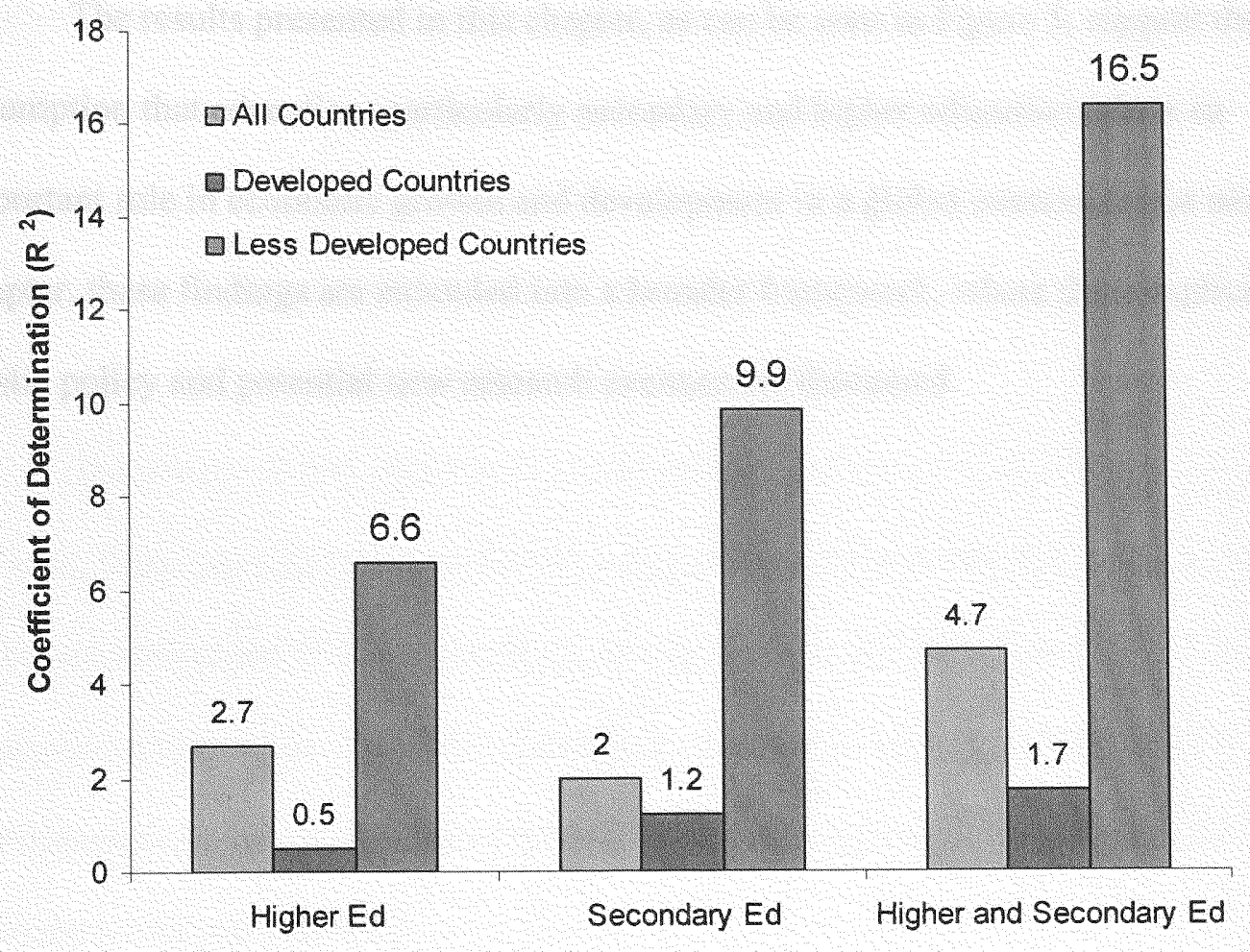

Variables

Figure 5. Comparison of the per capita income variance explained by changes in higher education and secondary education in developed and less developed countries.

\section{Summary of Findings}

Higher education does not appear to work together with globalization on its relationship with the changes in people's income on a national level. Independently, as can be seen in Figure 1, however, they both are assumed to carry an important weight in the per capita income spread. With respect to higher education and economic 
development, the relationship between higher education and economic growth does not look to be as important in developed countries as it is in less developed ones. Finally, an interesting finding is that primary education does not seem to be as essential in explaining changes in per capita income as are the levels of secondary and higher education.

The results presented in this chapter, as can be seen in Figure 5, support the assumption that education, particularly secondary and higher education, plays an important role in economic growth and development in a global context. In the next chapter, these findings are extended into a broader framework, where their implication on public policy and potential new research avenues are discussed. 


\section{CHAPTER V \\ DISCUSSION AND CONCLUSIONS}

Empirical evidence in the existing literature supports the assumption that higher education contributes to economic growth. This research was conducted to determine whether globalization influences that contribution, and whether higher education also contributes to economic development. For that purpose, the findings of this study were expected to answer the following research question: Does higher education contribute to economic development in the context of globalization?

\section{Discussion of Findings}

The results of this study reply to the above research question with several answers. These answers address the following issues: (a) the independent contribution of higher education and globalization to economic growth and the contribution of their interaction, (b) the role of higher education in countries with different levels of economic development, and (c) the positive relationship between economic growth and the secondary level of education.

\section{Higher Education and Globalization}

The findings of this study indicate that the contribution of higher education to economic growth and development is not significantly related to the degree of globalization of the economy. Conversely, higher education and the level of globalization do independently explain changes in economic growth. That indicates that there is a relationship between higher education and the economy regardless of the source of the capital (national or foreign) invested in the country. Consequently, an increase in demand for higher education after an increase in the globalization of the economy should not be 
assumed to be caused by the ability of that country to attract foreign investment. It is more likely caused by the technology introduced by the multinational enterprises.

The findings of this study suggesting that globalization does not make the contribution of education to economic growth and development more substantial are consistent with the arguments of some researchers. According to Mallampally (1997) transnational corporations (TNC) offer significant formal and informal learning opportunities, and training and learning are directed toward all workers. He added that contributions to employees' knowledge, skills, and management expertise can be more widely dispersed in the host economy and complement domestic human resource development.

In a similar study, Hanson's (2006) findings revealed that education is not synonymous with schooling. He argues that knowledge is transferred from higher-tech TNCs to national institutions in less developed countries (LDC) and recipient countries use the acquired knowledge to move up national learning and development curves toward national development goals. According to Hanson and Mallampally (1997), globalization may bring their own source of training and transfer and could spread knowledge out of the host country's own education system, including higher education. That could be one of the reasons why globalization does not make the contribution of higher education to economic growth and development more substantial.

Two more aspects may be considered to explain why globalization does not appear to have an impact on the contribution of higher education to economic growth. One aspect may be a causality issue. This study focuses on the effect of globalization on higher education, and in developed countries it could be the other way around: higher 
education may have an effect on globalization. The considerable stock of human capital built by professionals graduated from well structured higher education systems in developed countries may lure foreign investors in the high technology sector. If this is the case, globalization would not have an impact in the contribution of higher education to economic development, but higher education would have an effect on globalization. The other aspect may be the motivation of foreign investors to invest in less developed countries. If multinational corporations want to operate in less developed countries only to take advantage of low-skilled/low-wage labor, the promotion and expansion of higher education would not motivate this kind of investment.

\section{Higher Education and Economic Development}

An interesting finding derived from this study is that when the model is run for the same countries, but grouped by their degree of development, the interaction of higher education and global production integration means that there is a differential effect. Therefore, higher education has a greater effect in developed countries than in less developed ones. The independent contribution of higher education to economic growth, however, is more remarkable in the group of less developed economies than in the group of more developed ones. This contradiction seems to stem from the degree of globalization of the economy. This assumption is based on the fact that the economy of developed countries is more globalized than the economy of less developed ones.

There has been a tendency to see the search for cheap labor as the main economic reason of globalization. In other words, that developed economies have been steering most of their foreign direct investments (FDI) to less developed ones. In 2002, however, of the world's $\$ 651.2$ billion FDI inflows, $\$ 460.3$ billion (75\%) went to developed 
economies and only $\$ 162.1$ billion (25\%) went to less developed ones (Sauvant, 2003). In other words, developed countries turn most of their FDI to also other developed economies and, therefore, their economies are more globalized than the economies of their less developed counterparts.

With respect to the interaction of higher education and global production integration, on the one hand, the economies of developed countries are highly globalized and, therefore, the contribution of higher education to economic growth is supposed to be considerably influenced by globalization. On the other hand, as less developed economies are less globalized than the economies in developed countries, the influence of globalization in the contribution of higher education to economic growth in those countries is less significant.

In regard to the positive relationship between higher education and economic growth, developed economies are supposed to have a stable source of higher education graduates that meets the demand of the workforce for professional, and changes in higher education, mainly addressed to replace depreciated human capital (Fedderke, 2002), do not explain significant changes in economic growth. Less developed economies, however, are more sensitive to changes in higher education. Those changes are not only addressed to replace depreciated human capital, but are also aimed to increase the production capability of the workforce to raise the level of technology in their effort to achieve economic development.

Secondary Education and Economic Development

Even though this study focuses on higher education, the primary and secondary levels were also included in the analysis. Primary education appears to be non-significant 
in the production process of the economy. Secondary education, however, accounts for even more of the unique variance than higher education in less developed countries. One reason could be that, according to the level of technology in those countries, the demand for qualified labor can be mainly met with graduates from the secondary level of education. Another reason could be that the main condition to achieve a college level is to complete first a secondary education. In other words, the secondary level of education in those economies feed both the workforce and the higher education system at a higher proportion than in their more developed counterparts.

The relationship of secondary education with economic growth and development that this study revealed seems to have motivated some research efforts. A recent study analyzed the effects of primary, secondary, and higher education in the economic growth of Zimbabwe during the period 1975-2004. The results of that study, which is in part consistent with this study, showed that there was a positive and significant relationship between secondary education and economic growth in Zimbabwe a less developed country. Primary and higher education however were insignificant in the economic growth of that country (Mupimpila, 2007).

In another study focusing on the relationship between secondary education and economic growth in LDC, Loening (2005) investigated the impact of human capital on economic growth in Guatemala during 1951-2002. The results showed that a bettereducated labor force had a positive and significant impact on economic growth. His study revealed that primary and secondary education levels are most important for productivity growth. Loening concluded that the human capital variables explained more than $50 \%$ of 
output growth, and of these, secondary schooling was the predominant determinant of growth.

\section{The Importance of Primary Education}

Higher education is the main focus of this study, and the inclusion of the preceding two levels had the purpose of finding how much changes in the whole education system explain changes in economic growth. Another purpose was to compare the results of the other two levels and compare them with the results of higher education. This last purpose was well asserted since the findings show that secondary education explains even more variance of economic growth than higher education, mainly in less developed countries. Primary education, however, does not contribute as much to economic growth and development as the two following levels..

The coefficient of primary education in this model is not statistically significant, and I expected those results. The reason of this assumption was that, according to the criteria used to select the countries included in this study, the proportion of members of the workforce in those economies with only a primary level of education is not great enough as to really impact the economy. If the model used in this study were run using different criteria to group the countries, primary education could have resulted more significant. The results of a recent study are consistent with this assumption. Masanjala and Papageorgiou (2008) took a fresh look at Africa's growth experience by using the Bayesian model averaging (BMA) methodology. Posterior coefficient estimates revealed that key engines of growth in Africa are substantially different from those in the rest of the world. More precisely, it was shown that initial primary education exerted differential effect on African growth. 
The fact that primary education is not statistically significant in this model, however, does not mean that its role in the economy is not important. If a child never takes his firs step, he will never be a successful Olympic runner later in life. Likewise, if a child does not complete the primary level of education, he will never be a successful college graduate professional later in life. The economic contribution of primary education completion is not its immediate impact in the production process, but in the cumulative amount of knowledge embedded in those graduating at the secondary and higher education levels.

\section{Significance of the Study}

The results of this study confirm the evidence in the existing literature that higher education contributes to economic growth, regardless of a country's level of development and globalization. It is found, however, that this contribution seems to be more significant in less developed economies, and that the role of secondary education is even more significant in those countries. Based on these findings, this study suggests that public policy should be designed and implemented to develop an adequate educational system that meets the requirements of achieving and keeping economic development.

\section{Developed Countries}

Even though the changes in higher education in developed countries do not appear to make significant changes in economic growth, it is important for them to keep an adequate level of graduated professionals to constantly improve the level of technology and stay competitive in the global market. The new roles of higher education facing globalization in developed countries have recently been the subject of study of researchers, such as Bosworth, Jones, and Wilson (2008); Gornitzka and Langfeldt 
(2008); and Blum (2008). It is important for national enterprises that their domestic economies keep sufficient levels of development to maintain the purchasing power of consumers and facilitate the sale of their products. It is also important for enterprises operating globally, therefore, that their less developed host countries achieve adequate levels of economic development so that the purchasing power of the local consumer is enough to purchase their production.

As the findings of this study may increase public policy and private sector awareness of the importance of the development of an adequate formal education system, it should also be a concern of multinational enterprises to contribute to the economic development of their host countries by helping in the development of adequate education systems. The convenience for those enterprises would be twofold. On the one hand, a more educated population could be translated into an increase in the purchasing power of their local consumers. On the other hand, an increase in secondary and higher education graduates could meet the demand of those enterprises' technology for qualified labor.

An example of multinational corporations helping in the development of education systems can be seen in the United States. Two multinational companies have unveiled projects to improve the international standing of U.S. students in mathematics and science. The GE Foundation was expected to award grants totaling $\$ 100$ million over five years to five school districts around the country in an effort to boost the districts' math and science scores and increase their numbers of graduates going on to college. Moreover, the IBM International Foundation also stated its intention to help train up to 100 of its employees to become math and science teachers in K-12 schools (Borja, 2005). 
A great significance of this study is that the development of secondary education in less developed countries is even more significant than the expansion of higher education. That does not mean that all the resources dedicated to education should be allocated to the secondary level. Instead, those resources should be proportionally distributed between the two levels. Even though the findings of this study may increase the awareness of public and private policymakers about the role of education in the economy, it is the public sector the must important factor in the development of an adequate education system in less developed countries.

The widespread move toward a free basic education for all in developing nations has raised parents' and policymakers' interest in secondary education. In general, policymakers in such countries, as well as many development strategists, believe that there is a link between secondary education and the opportunity to compete vigorously in a global economy (Keller, 2005).

\section{Corporate Social Responsibility}

Private decision makers in developed countries and public policymakers in less developed ones, therefore, should play their corresponding roles to promote education as a way to achieve and maintain economic development. With respect to the private sector in developed countries, it is convenient for corporations to assume social responsibility at home and in host countries, at least for the sake of their successful operation. As social responsible behavior has become common practice among some large corporations, Corporate Social Responsibility (CSR) has become the subject of some sectors of research. 
Although the concept of CSR has been developing since the early1970s, there is no single, commonly accepted definition of CSR, and there are different perceptions of the concept among governments, the private sector, and civil society organizations (Kyte, 2008). According to Kyte, CSR may include, depending on one's perspective, (a) a company running its business responsibly in relation to internal stakeholders (shareholders, employees, customers, and suppliers), (b) the role of business in relationship to the state, locally and nationally, as well as to inter-state institutions or standards, and (c) business performance as a responsible member of the society in which it operates and the global community.

With respect to the public sector in less developed countries, corporate social responsibility may be used as a tool to encourage the private sector to get involved in the process of promoting education. Policymakers should consider, however, that according to Kite (2008), CSR is voluntary and goes beyond existing regulations. She argues that CSR is a complement to, not a substitute for, regulation, and that it can be encouraged and rewarded by effective regulation of the market. Public policy should be implemented, not to restrict the market, but to facilitate its operation for the wellbeing of society. Only if a social responsible behavior leads to a profitable operation, business firms will behave responsibly. Companies that have excelled at CSR would note that it strengthens the bottom line, enhances brand value, helps penetrate new markets, and creates business opportunities (Kyte, 2008).

New Windows into Research

This has been a very comprehensive study realized through the design and development of a linear model. The regressions of the model were run with data arising 
from 25 years of information of 10 indicators reported by 91 countries. Much more finding could have been obtained, but expanding this research even further would have taken this study out of its specific scope. This study is delimited to the analysis of the contribution of higher education to economic growth and development from a perspective of change. This is a generalized analysis, and it is just the starting point of a much broader research into more specific aspects in this area. This means that this investigation has open new windows into research.

\section{The Perspective of Change}

This study is about change. A change in a variable between the beginning and the end of the period used for this study explains part of the change in economic growth from the beginning to the end of the same period. My interest in studying change instead of absolute value is because economic and public policies are also about change. A policy is usually the implementation of a change (e.g., change in productivity) with the purpose of changing something else (e.g., change in output) According to this model, if public policy is implemented to make higher education completion increase, it is assumed that an increase in per capita income will also occur. The findings of this study, therefore, may persuade policymakers to promote changes to enhance and improve the education system, mainly in less developed countries, as a way to achieve economic growth and development.

\section{Research Timeframe}

Even though this study was done within the 10-year timeframe that better fitted the period of the global market expansion, this model is strong and statistically significant and can be tested in more comprehensive or specific timeframes. The global economy has 
become very dynamic and is constantly affected by many events that make it very difficult to predict. Running this model within different timeframes and comparing the results could lead to new and interesting findings. Absolute Value Perspective-Analysis-by-Year

A different timeframe could be reducing it to a one-year period. A static version of this model, which would measure not change but the absolute value of its variables, would be used for that timeframe. Instead of time series, that analysis would use the data of all the selected countries of one particular year. The purpose of that analysis would be to find how significant the global contribution of education to economic growth and development would be in a particular year. A useful tool for policymakers would be to compare the significance of that contribution of recent years with earlier years.

Country-by-Country Analysis

The other research alternative that I recommend using this model from the perspective of change, like in this study, is country-by-country analysis. The statistical technique of this study using a timeframe of only 10 years would not be robust enough if it were disaggregated at that level. For that research, therefore, the timeframe should be expanded instead. The purpose of that analysis would be to find how substantial the contribution of education to economic growth and development would be in a particular country. The results of that analysis would be helpful to the policymakers of that country for the design and implementation of education policies for the development of the economy. 


\section{Comparative Education}

The country-by-country and analysis-by-year approaches would be very valuable to comparatists and those investigating higher education developments. According to Cook, Hite, and Epstein (2004), comparative education has developed a body of literature that can be investigated to ascertain patterns of the field's growth, the advent of schools of thought, and the building of a knowledge base. This study is also addressing the main concerns in the field of comparative education. To examine the field's contemporary dimensions, Cook et al. conducted a survey of comparativists and their literature to discern how perceptions of the field converged. A total frequency of 565 times corresponded to the 10 most frequently named themes in comparative education. Among them, globalization ranked in the first place, which was named 105 times, and education and development in the third place, which was named 62 times (Cook, Hite, \& Epstein, 2004).

\section{Analysis by Other Categories}

Given that there is a difference in findings between countries with different levels of development, maybe future research might find even more interesting results if countries were examined by other categories. A limitation of this study was the exclusion of few countries with missing data in time series, which were otherwise included in this study. This is a common problem when studying poor countries with limited data reporting capabilities. Splitting the countries selected for this study by different categories, therefore, could give place to small groups that could compromise the statistical strength of the model. If this model, however, were run in the future using a more recent timeframe, the number of countries without missing data might be increased. 
Then, this model might be run for countries grouped by additional categories, such as regions (e.g., Latin-American, African, and Asian countries), emerging nations, transitioning economies, and newly developed countries.

According to Ilon (2009), higher education has shifted from a local service to a globally competitive business. Any comprehensive research involving education and economic growth and development, therefore, should be conducted in a global context. It is also important to consider that, in a globalized environment, some countries share similar social, economic, cultural, and/or geographical aspects that could lead research to more accurate findings if countries are grouped by different categories. In studies like this, authors such as Petrakis and Stamatakis (2002) and Ramcharan (2004) have found success in analyzing the effect of education by dividing counties according to their level of development. Other authors, however, have been successful in their analysis of education and its economic impact by grouping countries according to other categories.

In a study of two groups of countries, Spagat (2006) found that transition economies-those changing from a centrally planned economy to a free market economy - were assumed to have higher human capital relative to GDP per capita than developing economies. Spagat compared in his study the results of countries grouped according to their level of development, with the results of countries falling under the category of transition economies. Morote (2001) also conducted research grouping countries according to categories other than level of development. In her study, she explored the relationship between higher education and economic development in two Latin American emerging markets, Mexico and Peru. The purpose of Morote's study was to test empirically the relationship between higher education and economic growth in the 
presence and absence of a third variable: employment. Her findings suggested that higher education did help increase economic growth. In her study, Morote grouped for her study two countries sharing common characteristics that made them fall under two different categories. Geographically, the countries analyzed were found in the Latin American region, and at the same time, their economies fell under the emerging markets category.

\section{Labor Demand Pressures}

Further research on this topic will be needed to face the labor demand pressures imposed by the constant change of the labor demand structure. In the particular case of the United States, for example, auto mechanics were once trained mostly through handson experience. Now, a mechanic's work is $20 \%$ repair and $80 \%$ diagnostic. Automotive repair has become a field in which certification is required before the hood is lifted. In $1959,20 \%$ of the workforce in the United States possessed some postsecondary training. In 1995 , workers with the same training went up to $56 \%$, and in 2015 , the proportion is expected to go up to $76 \%$ (Gunderson, Jones, \& and Scanland, 2005).

\section{Enrollment and Retention}

Secondary education drop-outs and higher education enrollment and retention have been subjects of research mainly as social and psychological issues. This study alerts that these are also economic issues. Drop-outs, lack of enrollment, and poor retention are obstacles that prevent economic growth and development. Some studies, such as those of Fielding, Belfield, and Thomas (1998) and Barker (2007), referred to the cost of drop-outs to the educational institutions. Other studies, such as that of Maslen (1999), focused on how much drop-outs cost to taxpayers. I have not found in the existing literature, however, a study focusing specifically on the relationship of secondary 
drop-outs, lack of enrollment, and poor retention with economic growth and development.

In the particular case of the United States, the reduction of secondary education drop-outs and the increase in the retention rates in colleges and universities are very complex issues and they depend on many different factors. Higher education enrollment, however, stem mainly from lack of connection between the school districts and the higher education institutions. It would be very interesting to use this model to conduct research about the relationship between these issues and economic growth by adding to it predictor that measure secondary education drop-outs and higher education indexes of enrollment and retention.

\section{An Integrated Education System}

One purpose of this study is to make policymakers aware of the importance to promote higher education as a way to achieve economic development. Higher education is an option and public policy aiming to its enhancement should address the two participants in the educational process: those providing higher education (policymakers and administrators) and those receiving the benefits of it (students). Primary and secondary education, however, are either compulsory or socially indispensable, and the role of public policy is not precisely to enhance it but to improve it. A comprehensive policy to enhance higher education, therefore, must include the improvement and development of the primary and secondary levels of education as well.

Part of the improvement of the preceding levels of higher education should be the establishment and maintenance of connections between the three levels. Policymakers and administrators at both primary and secondary levels seem to be concerned mainly 
with the students' completion of their respective level, without regard of what will happen next to those students. The three levels of education should be integrated into only one education system, and the goal of every policymaker, administrator, and student should be the completion of that integral education system at the college level. The option should not be whether students will go to college or not, but at what level of college they will graduate - associate, bachelor, master, or doctoral level. A comprehensive policy for the development of education from the primary level up would be the best policy to promote and develop higher education.

According to Schmidt (2006), about 28 states in the United States are pulling together elementary, secondary, and college educators and putting them through such exercises in hopes of finding ways to improve educational achievement. He explains that the state endeavors are generally known as "K-16 initiatives," reflecting their focus on education from kindergarten through college, or as "P-16 initiatives," with the P meaning preschool. Schmidt argues that they operate on the assumption that education leaders at all levels, from colleges on down, must be at the table if states are to find effective ways to turn around troubled public schools and substantially increase high-school and college graduation rates.

\section{Conclusion}

This study was motivated by the increasing demand of national economies for human capital to remain competitive in the global market. It focused on formal education, mainly higher education, which is believed to be a reliable and stable source of human capital with the capacity of being modified and expanded through the implementation of public policy. Thus, the results of this research are expected to increase public policy and 
private sector awareness of the importance of developing an adequate formal education system, with emphasis in higher education, to meet the demand for human capital.

The results of this study answered the research question: Does higher education contribute to economic development in the context of globalization? Indeed, higher education does appear to contribute to economic development regardless of the degree of globalization of the economy. The findings of this investigation went even beyond the mere answer to the research question. They support the assumption that higher education plays a more significant role in less developed countries than in more developed ones, and that the role of secondary education in those countries is even more substantial than the role of higher education.

I have learned from doing this research, on the one hand, that even though causality may seem to be very evident when observing the behavior of particular variables, the completion of a statistical analysis may suggest that a cause-effect relationship between them does not exist. On the other hand, I have also learned that the result of a statistical analysis may suggest the existence of causality between observed variables, which were not showing any evidence of relationship before the analysis. I arrived at these conclusions based on two important findings of this study. First, the findings suggested that the causality that I expected between the higher education and globalization interaction and economic growth was not supported. Also important was the surprising finding that the effect of secondary education on economic growth in less developed countries was even more substantial than the effect of higher education there. These conclusions, however, do not make me think that I should have done this research differently. The reason is because I also learned from this study that research is like 
opening a window to the unknown, where we may not find what we expect and where we may also find the unexpected.

This is not, therefore, definitive research. This is just the starting point of a much broader research endeavor. It is hard to convince policymakers about the importance of education for the economy, since the returns of investments in education are not seen for a long time. More research about the relationship between education and economic growth and development is necessary to influence the allocation of resources in favor of education. This study has shown how changes in completion at different levels of education appear to be related to economic growth at various stages of economic development. Research is still needed. For example, to better establish the relationship between workforce development and educational investment and how different rates of enrollment and retention relate to the economy. If it is important to study the relationship of education with individual and social development, it is also important to study the relationship of education with economic growth and development. 


\section{REFERENCES}

Abel, A. B., \& Bernanke, B. S. (1995). Macroeconomics (2nd ed.). Reading, MA: Addison-Wesley.

Agiomirgianakis, G., Asteriou, D., \& Monastiriotis, V. (2002). Human capital and economic growth revisited: A dynamic panel data study. International Advances in Economic Research, 8(3), 177-187.

Ayers, R. M., \& Collinge, R. A. (2005). Macroeconomics: Explore \& apply. Upper Saddle River, N.J.: Pearson/Prentice Hall.

Balance of payments manual: Fifth edition (1993). Washington, DC: International Monetary Fund.

Barker, I. (2007). Drop-outs 'cost millions'. The Times Educational Supplement, 4747, 113.

Barro, R. J. (1984). Macroeconomics. New York: Wiley.

Barro, R. J., \& Lee, J. (2001). International data on educational attainment: Updates and implications. Oxford Economic Papers, 53(3), 541.

Becker, S. (1964). Human capital: A theoretical and empirical analysis, with special reference to education. New York: Columbia University Press.

Benhabib, J., \& Spiegel, M. (1992). The role of human capital in economic development (Economic Research Report No. RR\#92-46). New York: C. V. Starr Center for Applied Economics, New York University.

Beyond 20/20 WDS - report folders. (n.d.). Retrieved 10/18/2008, 2008, from http://stats.unctad.org/handbook/ReportFolders/ReportFolders.aspx

Blaug, M. (1992). The methodology of economics : Or, how economists explain (2nd ed.). Cambridge England; New York: Cambridge University Press.

Blum, D. W., ed. (2008). Russia and globalization: Identity, security, and society in an era of change Washington, D.C.:; Woodrow Wilson Center Press;; Baltimore:; Johns Hopkins University Press.

Borja, R. R. (2005). Companies unveil projects to improve math, science learning. Education Week, 25(5), 6-12.

Bosworth, D., Jones, P., \& Wilson, R. (2008). The transition to a highly qualified workforce. Education Economics, 16(2), 127-147. 
Boyes, W. J. (1984). Macroeconomics: The dynamics of theory and policy. Cincinnati: South-Western Pub. Co.

Branson, W. H. (1979). Macroeconomic theory and policy (2d ed.). New York: Harper \& Row.

Cobb, C. W., \& Douglas, P. H. (1928). A theory of production. The American Economic Review, $18(1$, Supplement, Papers and Proceedings of the Fortieth Annual Meeting of the American Economic Association), 139-165.

Cook, B. J., Hite, S. J., \& Epstein, E. H. (2004). Discerning trends, contours, and boundaries in comparative education: A survey of comparativists and their literature.(bibliography). Comparative Education Review, 48(2), 123-149.

Crocker, R. K. (2002). Learning outcomes: A critical review of the state of the field in Canada (Submitted to the Canadian Education Statistics Council). Ottawa, Canada.

Denison, E. F. (1961). Sources of economic growth in the U. S. New York: Committee of Economic Development.

Detailed benchmark definition of foreign direct investment: Third edition (1996). Paris: Organization for Economic Co-operation and Development.

Domar, E. D. (1957). Essays in the theory of economic growth. New York: Oxford University Press.

Egger, H., Egger, P., Falkinger, J., \& Grossmann, V. (2005). International capital market integration, educational choice and economic growth. Munich: Univ., Center for Economic Studies [u.a.].

Fedderke, J. (2002). Technology, human capital, growth and institutional development: Lessons from endogenous growth theory? Theoria, 100, 1-26.

Fielding, A., Belfield, C. R., \& Thomas, H. (1998). The consequences of drop-outs on the cost-effectiveness of 16-19 colleges. Oxford Review of Education, 24(4), 487-511.

Folson, R. B. (2006). Educational viability and development: A sub-Saharan experience. Journal of Educational Thought, 40(1), 75-94.

Gaither, N., \& Gray, V. D. (1996). Study guide for production and operations management: Seventh edition by Norman Gaither. Belmont, CA: Duxbury Press.

Galindo Martin, M., \& Alvarez Herranz, A. (2004). Human capital and economic growth in Spanish regions. International Advances in Economic Research, 10(4), 257-264. 
Gornitzka, A., \& Langfeldt, L., eds. (2008). Borderless knowledge: Understanding the 'new' internationalisation of research and higher education in Norway Higher Education Dynamics series, vol. 22; New York: Springer.

Gunderson, S., Jones, R., \& and Scanland, K. (2005). The jobs revolution: Changing how America works (2nd ed.). Chicago, IL: Copywriters, Inc.

Hanson, M. (2006). Transnational corporations as educational institutions for national development: The contrasting cases of Mexico and South Korea. Comparative Education Review, 50(4), 625-650.

Harrod, R. F. (1948). Towards a dynamic economics: Some recent developments of economic theory and their applications in policy (1st ed.). London: Macmillan.

Hirschman, A. (1958). The strategy of economic development. New Haven, CT: Yale University Press.

Holt, M. (2001). The comprehensive high school in the United States: A view from Europe and the United Kingdom. Journal of Curriculum and Supervision, 16(2), 137-161.

Hoxby, C. (1999). The productivity of schools and other local public goods providers. Journal of Public Economics, 24, 1-30.

Human development reports - United Nations Development Programme. (n.d.). Retrieved March 2, 2008, from http://hdr.undp.org/en/

Hunter, A. A. (1988). Formal education and initial employment: Unraveling the relationships between schooling and skills over time. American Sociological Review, $53(5), 753$.

Hyman, D. N. (1986). Modern microeconomics: Analysis and applications. St. Louis, MO: Times Mirror/Mosby College Publishing.

Ilon, L. (2009). Higher education responses to global economic dynamics. Unpublished manuscript, Seoul National University.

Katz, M. H. (2006). Study design and statistical analysis: A practical guide for clinicians. Cambridge: Cambridge University Press.

Keller, K. R. I. (2006). Investment in primary, secondary, and higher education and the effects on economic growth. Contemporary Economic Policy, 24(1), 18-34.

Kenwood, A. G., \& Lougheed, A. L. (1999). The growth of the international economy 1820-2000: An introductory text (4th ed.). New York: Routledge. 
Kyte, R. (2008). Balancing rights with responsibilities: Looking for the global drivers of materiality in corporate social responsibility \& the voluntary initiatives that develop and support them. American University International Law Review, 23(3), 559-576.

Loening, J. L. (2005). Effects of primary, secondary, and tertiary education on economic growth: Evidence from Guatemala. The World Bank, Policy Research Working Paper Series: 3610.

MacIntyre, A. (2001). Institutions and investors: The politics of the economic crisis in Southeast Asia. International Organization, 55(1), 81-122.

Maillet, B. B., \& Michel, T. L. (2005). The impact of the $9 / 11$ events on the American and French stock markets. Review of International Economics, 13(3), 597-611.

Makki, S. S., \& Somwaru, A. (2004). Impact of foreign direct investment and trade on economic growth: Evidence from developing countries. American Journal of Agricultural Economics, 86(3), 795-801.

Mallampally, P. (1997). Transnational corporations and human resource development. Prospects (Paris, France), 27, 55-76.

Mankiw, N. G., Romer, D., \& and Weil, D. N. (1992). A contribution to the empirics of economic growth. Quarterly Journal of Economics, 107, 407-437.

Mansfield, E. \& Behravesh, N. (2001). Economics USA (6th ed.). New York: W. W. Norton and Company.

Martin, R., \& Sunley, P. (1998). Slow convergence? The new endogenous growth theory and regional development. Economic Geography, 74(3), 201-227.

Masanjala, W. H., \& Papageorgiou, C. (2008). Rough and lonely road to prosperity: A reexamination of the sources of growth in Africa using Bayesian model averaging. Journal of Applied Econometrics, 23(5), 671-682.

Maslen, G. (1999). Oz gets tough on drop-outs. The Times Higher Education Supplement, 1390, 13-34.

McConnell, C. R., \& Brue, S. L. (2002). Economics: Principles, problems, and policies (15th ed.). New York: Irwin McGraw-Hill.

McConnell, C. R., \& Brue, S. L. (2005). Economics: Principles, problems, and policies (16th ed.). New York, NY: Irwin McGraw-Hill.

McNeil, K. A., Newman, I., \& Kelly, F. J. (1996). Testing research hypotheses with the general linear model. Carbondale and Edwardsville: Southern Illinois University Press. 
Mitchell, J. V. (2006). A new era for oil prices. Massachusetts Institute of Technology, Center for Energy and Environmental Policy Research, Working Papers.

Morote, E. (2001). Relationship among higher education, economic growth and employment in the leading Latin American emerging economies. (Doctoral Dissertation, University of Pittsburgh). Dissertation Abstracts International, A 62 (05), 1749.

Mowery, D. C., \& Rosenberg, N. (1989). Technology and the pursuit of economic growth. New York: Cambridge University Press.

Mupimpila, C. (2007). Human capital and economic growth in Zimbabwe. Asian-African Journal of Economics and Econometrics, 7(1-2), 331-343.

Myrdal, G. (1974). What is development? Journal of Economic Issues, 8(4), 729-736.

Pearl, J. (2000). Casuality: Models, reasoning, and inference. New York: Cambridge University Press.

Petrakis, P. E., \& Stamatakis, D. (2002). Growth and educational levels: A comparative analysis. Economics of Education Review, 21(5), 513-521.

Prebisch, R. (1988). Dependence, interdependence and development. CEPAL Review, 34, 197-205.

Quist, H. O. (2003). Transferred and adapted models of secondary education in Ghana: What implications for national development? International Review of Education, 49(5), 411-431.

Ramcharan, R. (2004). Higher or basic education? the composition of human capital and economic development. IMF Staff Papers, 51(2), 309-326.

Rostow, W. W. (1990). The stages of economic growth: A non-communist manifesto (3rd ed.). New York: Cambridge University Press.

Samuelson, P. A., \& Nordhaus, W. D. (1985). Economics (12th ed.). New York: McGraw-Hill.

Sauvant, K. P. (2003). World investment report 2003 FDI policies for development: National and international perspectives. Geneva, Switzerland: United Nations Conference on Trade and Development (UNCTAD).

Schiller, B. R. (2006). The micro economy today (10th ed.). New York: McGrawHill/Irwin.

Schmidt, P. (2006). A tough task for the states. The Chronicle of Higher Education. B6-8. 
Schultz, T. W. (1961). Investment in human capital. American Economic Review, 51, 117.

Schultz, T. W. (2003). Investment in human capital. In E. Ostrom, \& T. K. Ahn (Eds.), Foundations of social capital (pp. 36-52) Elgar Reference Collection. Critical Studies in Economic Institutions, vol. 2; Cheltenham, U.K. and Northampton, MA. Elgar; distributed by American International Distribution Corporation, Williston, Vt.

Seers, D. (1997). The meaning of development. Development, 40(1), 39-45.

Shell, K. (1966). Toward A theory of inventive activity and capital accumulation. The American Economic Review, 56(1/2), 62-68.

Singer, H. W. (1989). The World Bank: Human face or facelift? Some comments in the light of the World Bank's annual report. World Development, 17, 1313-1316.

Solow, R. M. (1956). A contribution to the theory of economic growth. The Quarterly Journal of Economics, 70(1), 65-94.

Spagat, M. (2006). Human capital and the future of transition economies. Journal of Comparative Economics, 34(1), 44-56.

Statistics - Human Development Reports (UNDP). (n.d.). Retrieved October 5, 2008, from http:/hdr.undp.org/en/statistics/

Teferra, D., \& Altbach, P. G. (2004). African higher education: Challenges for the 21 st century. Higher Education, 47(1), 21-50.

Torres, C. A. (2002). Globalization, education, and citizenship: Solidarity versus markets? American Educational Research Journal, 39(2), 363-378.

UNCTAD.ORG FDI indices. (n.d.). Retrieved March 3, 2008, from http://www.unctad.org/Templates/Page.asp?intItemID=2468\&lang=1

UNCTAD.ORG inward FDI performance index: Methodology. (n.d.). Retrieved March 2, 2008, from $\mathrm{http} / / /$ www.unctad.org/Templates/WebFlyer.asp?intItemID=2469\&lang=1

UNCTAD.ORG inward performance: Results for 2004-2006. (n.d.). Retrieved August 31,2008 , from

http://www.unctad.org/Templates/WebFlyer.asp?intItemID=2471\&lang=1

United Nations Statistics Division - National Accounts. (n.d.) Retrieved October 18, 2008, from http://unstats.un.org/unsd/snaama/dnllist.asp

Vedder, R. (2004). Private vs. social returns to higher education: Some new crosssectional evidence. Journal of Labor Research, 25(4), 677-686. 
Walters, D. (2004). The relationship between postsecondary education and skill:

Comparing credentialism with human capital theory. Canadian Journal of Higher Education, 34(2), 97-124

World Economic Outlook Database October 2008. (n.d.) Retrieved October 18, 2008, from http://www.imf.org/external/pubs/ft/weo/2008/02/weodata/index.aspx

World Intellectual Property Organization. (2008). World patent report. Geneva, Switzerland: World Intellectual Property Organization. 
APPENDICES 
Appendix A - List of Countries with Calculated UNCTAD Inward FDI Performance Index 
List of Countries with Calculated UNCTAD Inward FDI Performance Index

$\begin{aligned} 1 & \text { Albania } \\ 2 & \text { Algeria } \\ 3 & \text { Angola } \\ 4 & \text { Argentina } \\ 5 & \text { Armenia } \\ 6 & \text { Australia } \\ 7 & \text { Austria } \\ 8 & \text { Azerbaijan } \\ 9 & \text { Bahamas } \\ 10 & \text { Bahrain } \\ 11 & \text { Bangladesh } \\ 12 & \text { Belarus } \\ 13 & \text { Belgium \& Luxembourg } \\ 14 & \text { Benin } \\ 15 & \text { Bolivia } \\ 16 & \text { Botswana } \\ 17 & \text { Brazil } \\ 18 & \text { Brunei Darussalam } \\ 19 & \text { Bulgaria } \\ 20 & \text { Burkina Faso } \\ 21 & \text { Cameroon } \\ 22 & \text { Canada } \\ 23 & \text { Chile } \\ 24 & \text { China } \\ 25 & \text { Colombia } \\ 26 & \text { Congo } \\ 27 & \text { Congo, Democratic Rep. of } \\ 28 & \text { Costa Rica } \\ 29 & \text { Côte d'Ivoire } \\ 30 & \text { Croatia } \\ 31 & \text { Cyprus } \\ 32 & \text { Czech Republic } \\ 33 & \text { Denmark } \\ 34 & \text { Dominican Republic } \\ 35 & \text { Ecuador } \\ & \end{aligned}$

36 Egypt

37 El Salvador

38 Estonia

39 Ethiopia

40 Finland

41 France

42 Gabon

43 Gambia

44 Georgia

45 Germany

46 Ghana

47 Greece

48 Guatemala

49 Guinea

50 Guyana

51 Haiti

52 Honduras

53 Hong Kong, China

54 Hungary

55 Iceland

56 India

57 Indonesia

58 Iran, Islamic Republic of

59 Ireland

60 Israel

61 Italy

62 Jamaica

63 Japan

64 Jordan

65 Kazakhstan

66 Kenya

67 Korea, Republic of

68 Kuwait

69 Kyrgyzstan

70 Latvia 
List of Countries with Calculated UNCTAD Inward FDI Performance Index (continued)

71 Lebanon

72 Libyan Arab Jamahiriya

73 Lithuania

74 Macedonia, TFYR

75 Madagascar

76 Malawi

77 Malaysia

78 Mali

79 Malta

80 Mexico

81 Moldova, Republic of

82 Mongolia

83 Morocco

84 Mozambique

85 Myanmar

86 Namibia

87 Nepal

88 Netherlands

89 New Zealand

90 Nicaragua

91 Niger

92 Nigeria

93 Norway

94 Oman

95 Pakistan

96 Panama

97 Papua New Guinea

98 Paraguay

99 Peru

100 Philippines

101 Poland

102 Portugal

103 Qatar

104 Romania

105 Russian Federation
106 Rwanda

107 Saudi Arabia

108 Senegal

109 Sierra Leone

110 Singapore

111 Slovakia

112 Slovenia

113 South Africa

114 Spain

115 Sri Lanka

116 Sudan

117 Suriname

118 Sweden

119 Switzerland

120 Syrian Arab Republic

121 Taiwan

122 Tajikistan

123 Tanzania, United Rep. of

124 Thailand

125 Togo

126 Trinidad and Tobago

127 Tunisia

128 Turkey

129 Uganda

130 Ukraine

131 United Arab Emirates

132 United Kingdom

133 United States

134 Uruguay

135 Uzbekistan

136 Venezuela

137 Viet Nam

138 Yemen

139 Zambia

140 Zimbabwe 
Appendix B - List of Countries in Barro-Lee Education Attainment Dataset 
Appendix B

List of Countries in Barro-Lee Education Attainment Dataset

\begin{tabular}{rlll}
1 & Afghanistan & 37 & El Salvador \\
2 & Algeria & 38 & Estonia \\
3 & Antigua \& Barb. & 39 & Ethiopia \\
4 & Argentina & 40 & Fiji \\
5 & Australia & 41 & Finland \\
6 & Austria & 42 & France \\
7 & Bahrain & 43 & Gambia \\
8 & Bangladesh & 44 & Germany, East \\
9 & Barbados & 45 & Germany, United \\
10 & Belgium & 46 & Germany, West \\
11 & Belize & 47 & Ghana \\
12 & Benin & 48 & Greece \\
13 & Bolivia & 49 & Guatemala \\
14 & Botswana & 50 & Guyana \\
15 & Brazil & 51 & Haiti \\
16 & Brunei & 52 & Honduras \\
17 & Bulgaria & 53 & Hong Kong \\
18 & Burundi & 54 & Hungary \\
19 & Cameroon & 55 & Iceland \\
20 & Canada & 56 & India \\
21 & Central Afr. R. & 57 & Indonesia \\
22 & Chile & 58 & Iran, I.R. of \\
23 & China & 59 & Iraq \\
24 & Colombia & 60 & Ireland \\
25 & Congo & 61 & Israel \\
26 & Costa Rica & 62 & Italy \\
27 & Croatia & 63 & Jamaica \\
28 & Cuba & 64 & Japan \\
29 & Cyprus & 65 & Jordan \\
30 & Czech & 66 & Kazakhstan \\
31 & Czechoslovakia & 67 & Kenya \\
32 & Denmark & 68 & Korea \\
33 & Dominica & 69 & Kuwait \\
34 & Dominican Rep. & 70 & Latvia \\
35 & Ecuador & 71 & Lesotho \\
36 & Egypt & 72 & Liberia \\
& & \\
\hline & &
\end{tabular}


Appendix B

List of Countries in Barro-Lee Education Attainment Dataset (continued)

$\begin{aligned} 73 & \text { Libya } \\ 74 & \text { Lithuania } \\ 75 & \text { Malawi } \\ 76 & \text { Malaysia } \\ 77 & \text { Mali } \\ 78 & \text { Malta } \\ 79 & \text { Mauritania } \\ 80 & \text { Mauritius } \\ 81 & \text { Mexico } \\ 82 & \text { Moldova } \\ 83 & \text { Mozambique } \\ 84 & \text { Myanmar (Burma) } \\ 85 & \text { Namibia } \\ 86 & \text { Nepal } \\ 87 & \text { Netherlands } \\ 88 & \text { New Zealand } \\ 89 & \text { Nicaragua } \\ 90 & \text { Niger } \\ 91 & \text { Norway } \\ 92 & \text { Pakistan } \\ 93 & \text { Panama } \\ 94 & \text { Papua New Guin. } \\ 95 & \text { Paraguay } \\ 96 & \text { Peru } \\ 97 & \text { Philippines } \\ 98 & \text { Poland } \\ 99 & \text { Portugal } \\ 100 & \text { Puerto Rico } \\ 101 & \text { Reunion } \\ 102 & \text { Romania } \\ 103 & \text { Rwanda } \\ 104 & \text { Senegal } \\ 105 & \text { Seychelles } \\ 106 & \text { Sierra Leone } \\ 107 & \text { Singapore } \\ & \end{aligned}$

108 Slovakia

109 Slovenia

110 Solomon Islands

111 South Africa

112 Spain

113 Sri Lanka

114 St.Kitts\& Nevis

115 St.Lucia

116 St.Vincent \& G.

117 Sudan

118 Swaziland

119 Sweden

120 Switzerland

121 Syria

122 Taiwan

123 Tajikistan

124 Thailand

125 Togo

126 Trinidad \& Tobago

127 Tunisia

128 Turkey

129 U.S.S.R.

130 Uganda

131 United Arab Em.

132 United Kingdom

133 United States

134 Uruguay

135 Vanuatu

136 Venezuela

137 Viet Nam

138 Western Samoa

139 Yugoslavia

140 Zaire

141 Zambia

142 Zimbabwe 
Appendix C - List of Countries with Calculated UNDP Human Development Index (HDI) 
List of Countries with Calculated UNDP Human Development Index (HDI)

Albania

2 Algeria

4 Antigua and Barbuda

5 Argentina

6 Armenia

7 Australia

8 Austria

9 Azerbaijan

10 Bahamas

11 Bahrain

12 Bangladesh

13 Barbados

14 Belarus

15 Belgium

16 Belize

17 Benin

18 Bhutan

19 Bolivia

20 Bosnia and Herzegovina

21 Botswana

22 Brazil

23 Brunei Darussalam

24 Bulgaria

25 Burkina Faso

26 Burundi

27 Cambodia

28 Cameroon

29 Canada

30 Cape Verde

31 Central African Republic

32 Chad

33 Chile

34 China

35 Colombia
36 Comoros

37 Congo

38 Congo, Dem

39 Costa Rica

40 Côte d'Ivoire

41 Croatia

42 Cuba

43 Cyprus

44 Czech Republic

45 Denmark

46 Djibouti

47 Dominica

48 Dominican Republic

49 Ecuador

50 Egypt

51 El Salvador

52 Equatorial Guinea

53 Eritrea

54 Estonia

55 Ethiopia

56 Fiji

57 Finland

58 France

59 Gabon

60 Gambia

61 Georgia

62 Germany

63 Ghana

64 Greece

65 Grenada

66 Guatemala

67 Guinea

68 Guinea-Bissau

69 Guyana

70 Haiti 
Appendix C

List of Countries with Calculated UNDP Human Development Index (HDI) (continued)

71 Honduras

72 Hong Kong, China

73 Hungary

74 Iceland

75 India

76 Indonesia

77 Iran, Islamic Rep

78 Ireland

79 Israel

80 Italy

81 Jamaica

82 Japan

83 Jordan

84 Kazakhstan

85 Kenya

86 Korea, Rep

87 Kuwait

88 Kyrgyzstan

89 Lao, People's Dem

90 Latvia

91 Lebanon

92 Lesotho

93 Libyan Arab Jamahiriya

94 Lithuania

95 Luxembourg

96 Macedonia, TFYR

97 Madagascar

98 Malawi

99 Malaysia

100 Maldives

101 Mali

102 Malta

103 Mauritania

104 Mauritius

105 Mexico
106 Moldova

107 Mongolia

108 Morocco

109 Mozambique

110 Myanmar

111 Namibia

112 Nepal

113 Netherlands

114 New Zealand

115 Nicaragua

116 Niger

117 Nigeria

118 Norway

119 Occupied Palestinian Terr.

120 Oman

121 Pakistan

122 Panama

123 Papua New Guinea

124 Paraguay

125 Peru

126 Philippines

127 Poland

128 Portugal

129 Qatar

130 Romania

131 Russian Federation

132 Rwanda

133 Saint Kitts and Nevis

134 Saint Lucia

135 Saint Vincent

136 Samoa

137 São Tomé and Principe

138 Saudi Arabia

139 Senegal

140 Seychelles 
Appendix C

List of Countries with Calculated UNDP Human Development Index (HDI) (continued)

$\begin{aligned} 141 & \text { Sierra Leone } \\ 142 & \text { Singapore } \\ 143 & \text { Slovakia } \\ 144 & \text { Slovenia } \\ 145 & \text { Solomon Islands } \\ 146 & \text { South Africa } \\ 147 & \text { Spain } \\ 148 & \text { Sri Lanka } \\ 149 & \text { Sudan } \\ 150 & \text { Suriname } \\ 151 & \text { Swaziland } \\ 152 & \text { Sweden } \\ 153 & \text { Switzerland } \\ 154 & \text { Syrian Arab Republic } \\ 155 & \text { Tajikistan } \\ 156 & \text { Tanzania, U } \\ 157 & \text { Thailand } \\ 158 & \text { Timor-Leste } \\ 159 & \text { Togo }\end{aligned}$

141 Sierra Leone

142 Singapore

143 Slovakia

145 Solomon Islands

146 South Africa

147 Spain

149 Sudan

150 Suriname

151 Swaziland

153 Switzerland

154 Syrian Arab Republic

155 Tajikistan

156 Tanzania,

158 Timor-Leste

159 Togo
160 Tonga

161 Trinidad and Tobago

162 Tunisia

163 Turkey

164 Turkmenistan

165 Uganda

166 Ukraine

167 United Arab Emirates

168 United Kingdom

169 United States

170 Uruguay

171 Uzbekistan

172 Vanuatu

173 Venezuela, Rep

174 Viet Nam

175 Yemen

176 Zambia

177 Zimbabwe 
Appendix D - List of Countries in Barro-Lee Education Attainment Dataset with Calculated Inward FDI Performance Index and UNDP Human Development Index (HDI) Used in this Study 
List of Countries in Barro-Lee Education Attainment Dataset with Calculated Inward FDI Performance Index and UNDP Human Development Index (HDI) Used in this Study

$\begin{aligned} 1 & \text { Algeria } \\ 2 & \text { Argentina } \\ 3 & \text { Australia } \\ 4 & \text { Austria } \\ 5 & \text { Bahrain } \\ 6 & \text { Bangladesh } \\ 7 & \text { Belgium \& Luxembourg } \\ 8 & \text { Benin } \\ 9 & \text { Bolivia } \\ 10 & \text { Botswana } \\ 11 & \text { Brazil } \\ 12 & \text { Cameroon } \\ 13 & \text { Canada } \\ 14 & \text { Chile } \\ 15 & \text { China } \\ 16 & \text { Colombia } \\ 17 & \text { Congo } \\ 18 & \text { Costa Rica } \\ 19 & \text { Cyprus } \\ 20 & \text { Denmark } \\ 21 & \text { Dominican Republic } \\ 22 & \text { Ecuador } \\ 23 & \text { Egypt } \\ 24 & \text { El Salvador } \\ 25 & \text { Finland } \\ 26 & \text { France } \\ 27 & \text { Gambia } \\ 28 & \text { Germany } \\ 29 & \text { Ghana } \\ 30 & \text { Greece } \\ 31 & \text { Guatemala } \\ 32 & \text { Guyana } \\ 33 & \text { Haiti } \\ 34 & \text { Honduras } \\ 35 & \text { Hong Kong, China } \\ & \end{aligned}$

36 Hungary

37 Iceland

38 India

39 Indonesia

40 Iran, Islamic Rep. of

41 Ireland

42 Israel

43 Italy

44 Jamaica

45 Japan

46 Jordan

47 Kenya

48 Korea, Republic of

49 Kuwait

50 Malawi

51 Malaysia

52 Mali

53 Malta

54 Mexico

55 Mozambique

56 Nepal

57 Netherlands

58 New Zealand

59 Nicaragua

60 Niger

61 Norway

62 Pakistan

63 Panama

64 Papua New Guinea

65 Paraguay

66 Peru

67 Philippines

68 Poland

69 Portugal

70 Rwanda 
List of Countries in Barro-Lee Education Attainment Dataset with Calculated Inward FDI Performance Index and UNDP Human Development Index (HDI) Used in this Study (continued)

71 Senegal

72 Singapore

73 South Africa

74 Spain

75 Sri Lanka

76 Sudan

77 Sweden

78 Switzerland

79 Syrian Arab Republic

80 Thailand

81 Togo
82 Trinidad and Tobago

83 Tunisia

84 Turkey

85 Uganda

86 United Kingdom

87 United States

88 Uruguay

89 Venezuela

90 Zambia

91 Zimbabwe 
Appendix E - List of Countries in Barro-Lee Education Attainment Dataset Ranging from Mid-high to High Level of Development with Calculated UNCTAD Inward FDI Performance Index and UNDP Human Development Index (HDI) 


\section{Appendix E}

List of Countries in Barro-Lee Education Attainment Dataset Ranging from Mid-high to High Level of Development with Calculated UNCTAD Inward FDI Performance Index and UNDP Human Development Index (HDI)

$\begin{aligned} 1 & \text { Argentina } \\ 2 & \text { Australia } \\ 3 & \text { Austria } \\ 4 & \text { Bahrain } \\ 5 & \text { Belgium \& Luxembourg } \\ 6 & \text { Brazil } \\ 7 & \text { Canada } \\ 8 & \text { Chile } \\ 9 & \text { Costa Rica } \\ 10 & \text { Cyprus } \\ 11 & \text { Denmark } \\ 12 & \text { Finland } \\ 13 & \text { France } \\ 14 & \text { Germany } \\ 15 & \text { Greece } \\ 16 & \text { Hong Kong, China } \\ 17 & \text { Hungary } \\ 18 & \text { Iceland } \\ 19 & \text { Ireland } \\ 20 & \text { Israel } \\ 21 & \text { Italy }\end{aligned}$

22 Japan

23 Korea, Republic of

24 Kuwait

25 Malaysia

26 Malta

27 Mexico

28 Netherlands

29 New Zealand

30 Norway

31 Panama

32 Poland

33 Portugal

34 Singapore

35 Spain

36 Sweden

37 Switzerland

38 Trinidad and Tobago

39 United Kingdom

40 United States

41 Uruguay 
Appendix F - List of Countries in Barro-Lee Education Attainment Dataset Ranging from Mid-low to Low Level of Development with Calculated UNCTAD Inward FDI Performance Index and UNDP Human Development Index (HDI) 


\section{Appendix F}

List of Countries in Barro-Lee Education Attainment Dataset Ranging from Mid-low to Low Level of Development with Calculated UNCTAD Inward FDI Performance Index and UNDP Human Development Index (HDI)

1 Algeria

2 Bangladesh

3 Benin

4 Bolivia

5 Botswana

6 Cameroon

7 China

8 Colombia

9 Congo

10 Dominican Republic

11 Ecuador

12 Egypt

13 El Salvador

14 Gambia

15 Ghana

16 Guatemala

17 Guyana

18 Haiti

19 Honduras

20 India

21 Indonesia

22 Iran, Islamic Rep. of

23 Jamaica

24 Jordan

25 Kenya
26 Malawi

27 Mali

28 Mozambique

29 Nepal

30 Nicaragua

31 Niger

32 Pakistan

33 Papua New Guinea

34 Paraguay

35 Peru

36 Philippines

37 Rwanda

38 Senegal

39 South Africa

40 Sri Lanka

41 Sudan

42 Syrian Arab Republic

43 Thailand

44 Togo

45 Tunisia

46 Turkey

47 Uganda

48 Venezuela

49 Zambia

50 Zimbabwe 


\section{VITA}

\section{DOMINGO G. ECHEVARRIA}

February 2, 1945

1987

$1987-1988$

1989

$1984-2005$

$1992-2009$

$2005-2009$
Born, Havana, Cuba

B.A., Economics

Florida International University

Miami, Florida

Dean's List

Florida International University

Miami, Florida

Outstanding Academic Achievement Award

Florida International University

Miami, Florida

Graduate Research Assistant

Assistance in the preparation of the section

Economics, Handbook of Latin American Studies, volume 49, Social Studies, 1989 , edited by the Hispanic Division of the Library of Congress Florida International University

Miami, Florida

M.S., Public Administration

Florida International University

Miami, Florida

General Manager/Controller

Pool Discount Center, Inc.

Miami, Florida

Adjunct Instructor of Economics

Miami Dade College

Miami, Florida

Budget Analyst

City of Miami

Miami, Florida 